Key Words: Reactor Vessel Grout

Low-pH Grout

Flowable Fill

Retention: Permanent

\title{
BLENDED CALCIUM ALUMINATE- CALCIUM SULFATE CEMENT-BASED GROUT FOR P-REACTOR VESSEL IN-SITU DECOMMISSIONING (U)
}

David B. Stefanko and Christine A. Langton

Savannah River National Laboratory Savannah River Nuclear Solutions, LLC

Aiken, SC 29808

March 10, 2011

Savannah River National Laboratory Savannah River Nuclear Solutions, LLC Aiken, SC 29808

Prepared for the U.S. Department of Energy Under Contract No. DE- AC09-08SR22470

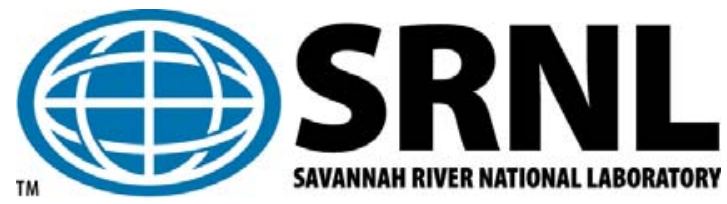




\section{DISCLAIMER}

This work was prepared under an agreement with and funded by the U.S. Government. Neither the U. S. Government or its employees, nor any of its contractors, subcontractors or their employees, makes any express or implied:

1. warranty or assumes any legal liability for the accuracy, completeness, or for the use or results of such use of any information, product, or process disclosed; or

2. representation that such use or results of such use would not infringe privately owned rights; or

3. endorsement or recommendation of any specifically identified commercial product, process, or service.

Any views and opinions of authors expressed in this work do not necessarily state or reflect those of the United States Government, or its contractors, or subcontractors.

Printed in the United States of America

Prepared for

U.S. Department of Energy

This document was prepared in conjunction with work accomplished under Contract No. DE-AC09-08SR22470 with the U.S. Department of Energy. 
Key Words: Reactor Vessel Grout Low-pH Grout

Flowable Fill

Retention: Permanent

\section{BLENDED CALCIUM ALUMINATE- CALCIUM HEMIHYDRATE CEMENT-BASED GROUT FOR P-REACTOR VESSEL IN-SITU DECOMMISSIONING (U)}

David B. Stefanko and Christine A. Langton

Savannah River National Laboratory Savannah River Nuclear Solutions, LLC

Aiken, SC 29808

March 10, 2011

Savannah River National Laboratory Savannah River Nuclear Solutions, LLC Aiken, SC 29808

Prepared for the U.S. Department of Energy Under Contract No. DE- AC09-08SR22470

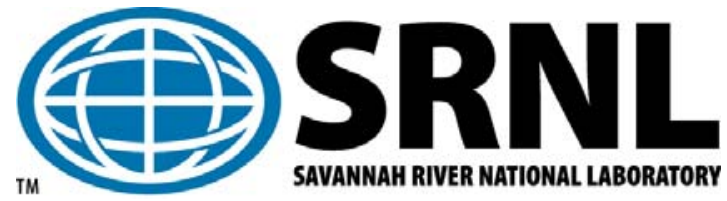




\section{REVIEWS AND APPROVALS}

\section{Authors:}

D. B. Stefanko, SRNL / E\&CPT / Advanced Characterization and Process Date

C. A. Langton, SRNL / E\&CPT / Engineering Process Development Date

Technical and SRNL Project Review:

M. G. Serrato, Technical Reviewer and Project Manager, SRNL /ES\&BT Date

SRNL Management Approvals:

A. B. Barnes, Manager, SRNL / E\&CPT

Date

S. L. Marra, Manager, SRNL / E\&CPT

Date

\section{Customer Approvals:}

J. K. Blankenship, SRNS, Area Completion Engineering, SDD Eng. Date

J. C. Musall, SRNS, Area Completion Engineering, SDD Eng.

Date 


\section{EXECUTIVE SUMMARY}

This report documents laboratory and scale-up testing of blended calcium aluminate - calcium hemihydrate grouts for P-Reactor vessel in-situ decommissioning (ISD). ${ }^{1}$ Blended calcium aluminate - calcium sulfate hemihydrate cement-based grout was identified as candidate material for filling (physically stabilizing) the 105-P Reactor vessel (RV) because it is less alkaline ${ }^{2}$ than portland cement-based grout which has a $\mathrm{pH}$ greater than 12.4. In addition, blended calcium aluminate - calcium sulfate hemihydrate cement compositions can be formulated such that the primary cementitious phase is a stable crystalline material. ${ }^{3}$ A less alkaline material $(\leq 10.5)$ was desired to address a potential materials compatibility issue caused by corrosion of aluminum metal in highly alkaline environments such as that encountered in portland cement grouts [Wiersma, 2009b, Wiersma, 2010, and Serrato and Langton, 2010]. Information concerning access points into the P-Reactor vessel and amount of aluminum metal in the vessel is provided elsewhere [Griffin, 2010, Stefanko, 2009a and Wiersma, 2009, Wiersma, 2010, Bobbitt, 2010, respectively]. Radiolysis calculations are also provided in a separate document [Reyes-Jimenez, 2010].

This work supports scope identified and authorized in TAR-SDD-2008-00133 [Musall, 2009a], TAR-SDD-2009-00231 [Musall, 2009b], and TT/QAP, SRNL-RP-2009-01248 [Stefanko, 2009b]. This work supports the SRS Reactor In-Situ Decommission Project and was funded by the American Recovery and Reinvestment Act.

Based on laboratory testing, 2:1 mixtures (by weight) of Ciment Fondu ${ }^{\circledR}$ to Plaster of Paris plus water had a slurry $\mathrm{pH}$ of 9 to 10 . Water in contact with cured specimens also had a $\mathrm{pH}$ of 9 to 10 . The primary reaction product for this cement system is ettringite, which is a thermodynamically stable crystalline solid. Amorphous aluminum hydroxide, which is compatible with the reactor materials of construction, is also present in the 2:1 Ciment Fondu ${ }^{\circledR}$ to Plaster of Paris mixtures. (Ciment Fondu ${ }^{\circledR}$ and Plaster of Paris are commercially available components.)

Grouts typically require inert fillers in addition to a suitable cement binder. A bimodal particle size distribution was selected for testing in the blended calcium aluminate - calcium sulfate cement grout based on earlier work on magnesium potassium phosphate flowable fills [Stefanko, Langton and Singh, 2010]. A Class F fly ash to quartz sand (ASTM C-404 masonry sand or

\footnotetext{
${ }^{1}$ SRNS/SDD-Engineering made the decision to fill the R-Reactor vessel with a portland cement based grout based on the amount of aluminum metal estimated to have been left in the vessel [Wiersma, 2009 a and b and Wiersma, 2010].

${ }^{2}$ Water in contact with calcium aluminate cement phases has a $\mathrm{pH}$ ranging from 10 to 11 depending on impurities. Water in contact with hydrated calcium sulfate compounds such as calcium sulfate hemihydrate has a $\mathrm{pH}$ between 5.5 to $8+$, depending on impurities. Consequently mixtures of these ingredients which hydrate to form stable cementitious materials were investigated for the P-Reactor fill application.

${ }^{3}$ Thermodynamically stable cementitious reaction products are an important feature of a durable material. Unstable reaction products that are initially cementitious but undergo phase changes and associated volumetric changes over time (densification or expansion) do not produce durable materials.
} 
ASTM C-637 Grade 2 sand) ratio of 1:3 (by weight) was selected because it is effective in reducing segregation and enhancing flow behavior.

The blended calcium aluminate - calcium sulfate cement grout required a set retarder as indicated by static working times of less than 15 minutes. Citric acid and boric acid were effective set retarders. A lower dose of citric acid was required compared to boric acid for the same set delay. Boric acid was selected for the scale-up testing and subsequently the final mix because it was available at Gibson's Pressure Grouting Services, Inc., during the scale-up testing.

Based on laboratory bench-scale and scale-up testing a calcium aluminate - calcium sulfate grout formulation was recommended for scale-up testing at Gibson's Pressure Grouting Services, Inc. This mix was one of two special formulations considered as candidates for the P-Reactor vessel ISD. The other mix was based on magnesium mono potassium phosphate cement and is described elsewhere [Stefanko, Langton and Singh, 2010].

The recommended mix design was confirmed in the full-scale mixing, pumping, and $1 / 4$ scale vessel filling test. Selected results are also included in this report. SRNL Mix T12-1 (Ciment Fondu $^{\circledR}, 9.06$ wt. \%; Plaster of Paris, 4.53 wt. \%; ASTM C-637 gradation 2 quartz sand, 51.56 wt. \%; Class F fly ash, 15.32 wt.\%; KIM ${ }^{\circledR} 301,0.135$ wt. \%; SIKA ViscoCrete ${ }^{\circledR} 2100,0.092$ wt. $\%$; boric acid, 0.10 wt. $\%$ (0.75 wt. $\%$ of the binder); diutan gum, 0.015 wt. $\%$; and water $19.18 \mathrm{wt} . \%$ is recommended for filling the SRS P-Reactor vessel. Ingredients and proportions for the recommended mix are listed below. (A formulation with a lower water to cementitious binder ratio was also designed and tested. This mix has lower hydraulic conductivity and higher strength. However, it was not recommended for filling the P-Reactor vessel because it was developed after the full scale processing and vessel mock up testing.)

\section{Blended Calcium Aluminate-Calcium Sulfate Grout Recommended for Filling the P- Reactor Vessel.}

\begin{tabular}{|c|c|c|}
\hline \multirow[b]{2}{*}{ Ingredient } & \multicolumn{2}{|c|}{ Water to binder weight 1.41} \\
\hline & $\left(\mathbf{L b s} / \mathbf{y d}^{3}\right)$ & $\left(\mathrm{Kg} / \mathrm{m}^{3}\right)$ \\
\hline $\begin{array}{l}\text { Ciment Fondu }^{\circledR} \\
\text { (Kerneos Aluminate Technologies) }\end{array}$ & 304.3 & 180.5 \\
\hline $\begin{array}{l}\text { Plaster of Paris } \\
\text { (US Gypsum Company) }\end{array}$ & 152.2 & 90.3 \\
\hline $\begin{array}{l}\text { Class F Fly Ash ASTM C-618 } \\
\text { (SEFA, Inc.) }\end{array}$ & 514.8 & 305.4 \\
\hline $\begin{array}{l}\text { ASTM C-404 Masonry sand or } \\
\text { ASTM C-637 Sand for grout for pre-placed } \\
\text { aggregate }\end{array}$ & 1732.0 & 1027.6 \\
\hline Water & 644.3 & 382.2 \\
\hline $\begin{array}{l}\text { KIM } 301^{\circledR} \text { (Integral Water Proofing Admixture) } \\
\text { (Kryton, International Inc.) }\end{array}$ & 4.5 & 2.7 \\
\hline SIKA ViscoCrete $^{\circledR} 2100$ (W.R. Grace, Inc.) & 3.1 & 1.8 \\
\hline Diutan Gum (CP Kelco, Inc.) & 0.5 & 0.3 \\
\hline Boric Acid (Technical grade) & 3.4 & 2.0 \\
\hline Total & 3359 & 1993 \\
\hline
\end{tabular}

* Proportions per unit volume were confirmed on large size batches. 
Pre-blending of all of the solid ingredients is recommended. Pre-blending provides quality control under "factory" conditions and disperses the solid ingredients in each other. Overall this shortens the grout mixing time in the field and simplifies full-scale production of this special material. Pre-measuring the SIKA ViscoCrete ${ }^{\circledR} 2100$ high range water reducer (HRWR) for each batch is also suggested. Chilled water is not necessary for the recommended mix for ambient and material temperatures up to $32^{\circ} \mathrm{C}$ provided that the grout is continually agitated and placed within an hour after solids addition. A minimum of 8 minutes of mixing (measured from the time all of the solids are added to the water) is required to achieve uniform properties at the fullscale mixing.

The mixing and pumping equipment used in the full-scale mixing and pumping tests are suitable for full-scale production, i.e., double tub 25 cubic foot paddle mixer with a 25 cubic foot agitated hold tank, PUMPAC hydraulically driven ball and seat pump with a two stage piston, and two inch flexible grout hose up to $400 \mathrm{ft}$ in length. Based on the scale-up test results, the grout can be dropped at least 20 feet without segregating. Consequently a tremie is not necessary for filling the reactor vessel. In addition, the blended calcium aluminate - calcium sulfate cement grout formulation has a dynamic working time of more than one hour. Consequently, in an upset condition, grout in the mixer and hose can be re-circulated for up to one hour without adversely affecting fresh and cured properties while the process is brought back on line.

\section{Post Script}

On November 18 and 22, 2010, SRNS in conjunction with Baker Concrete Construction and Gibson's Pressure Grouting Services, Inc., successfully completed filling the 105-P Reactor vessel with the blended calcium aluminate - calcium sulfate grout recommended by SRNL in accordance with the SRS Reactor Facility In-Situ Decommissioning requirements and SDD2010-00200, Revision 1, Grout Placement Strategy for 105-P Reactor Vessel [Griffin, 2010a]. A total of 118 cubic yards of material was placed in the vessel during the two days of fill operations (49 cubic yards on November 18 and 69 cubic yards on November 22). A photo of vessel filled to within 16 inches of the top is provided below (looking into an open circumferential sleeve position).

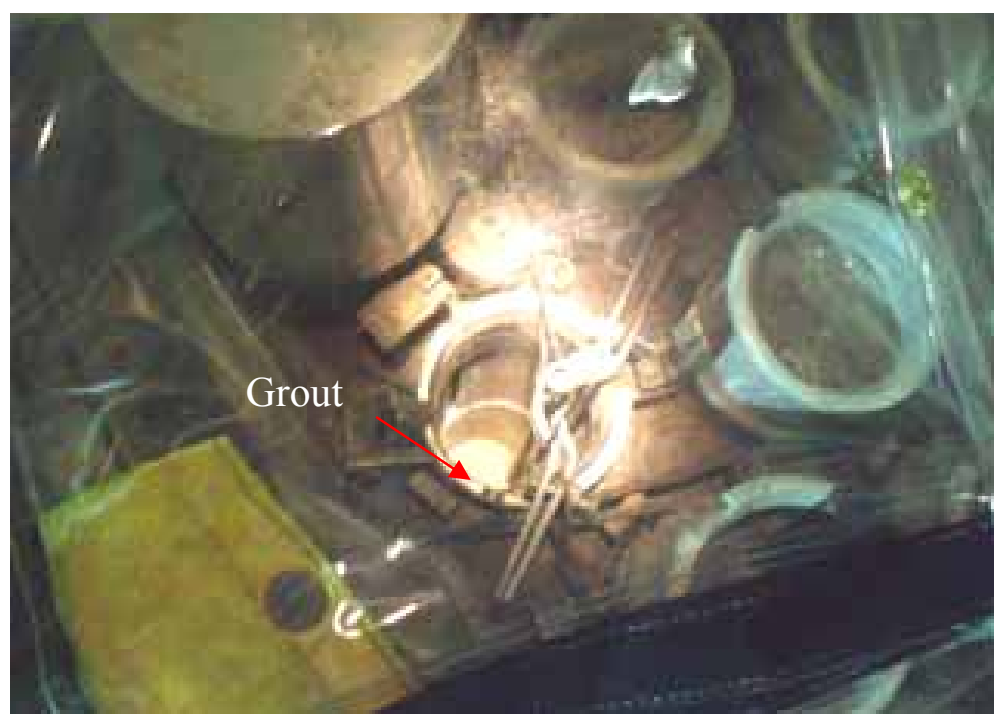




\section{TABLE OF CONTENTS}

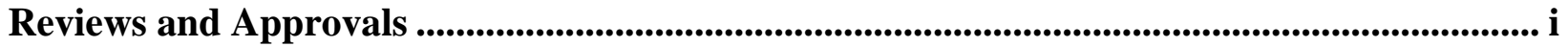

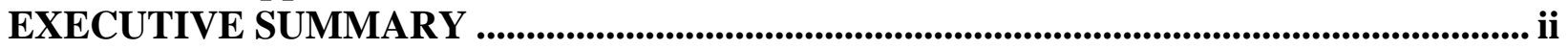

Table of Contents ..............................................................................................................................v

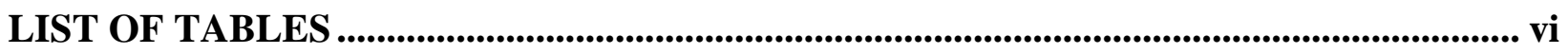

LIST OF FIGURES .................................................................................................................... vii

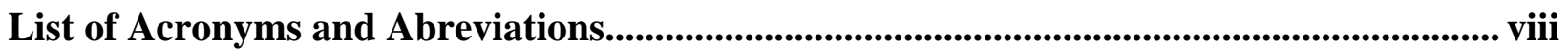

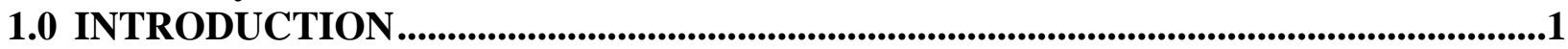

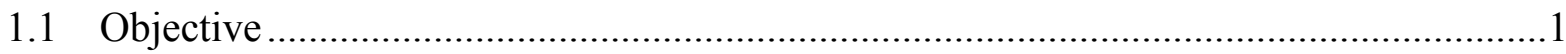

1.2 P-Reactor Vessel In-Situ Decommissioning ......................................................

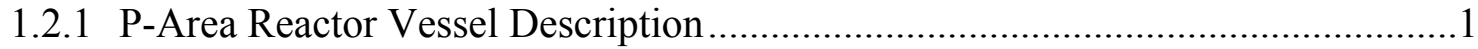

1.2.2 In-Situ Decommissioning Fill Requirements ...................................................

2.0 CALCIUM ALUMINATE CEMENT SYSTEMS ............................................................5

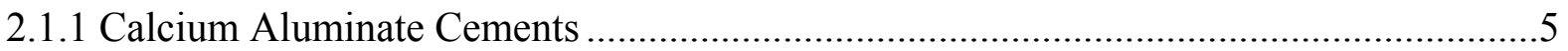

2.1.2 Calcium Sulfo-aluminate Cement...............................................................................5

2.1.3 Blended Calcium Aluminate - Calcium Hemihydrate Cement ...................................6

2.2 Blended Calcium Aluminate - Calcium Sulfate Hemihydrate Cement Grouts...............6

3.0 EXPERIMENTAL METHOD .......................................................................................8

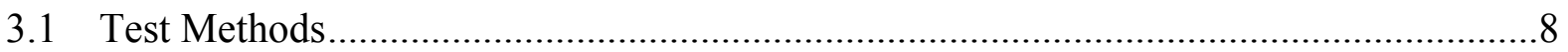

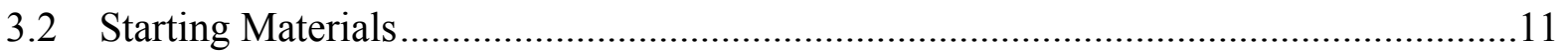

4.0 RESULTS: BLENDED CALCIUM ALUMINATE - CALCIUM SULFATE

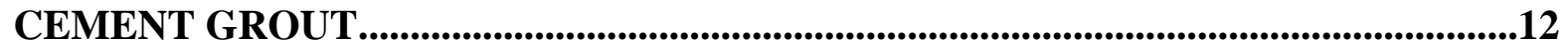

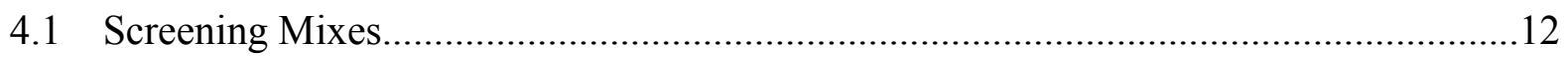

4.2 Laboratory Bench Scale-up and Test Results .................................................... 16

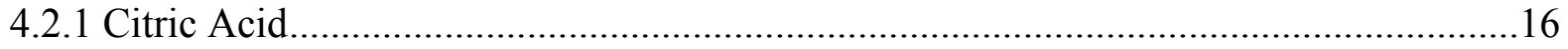

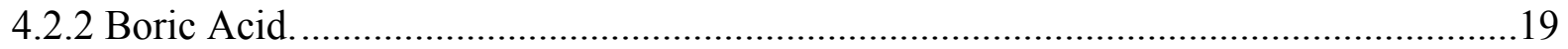

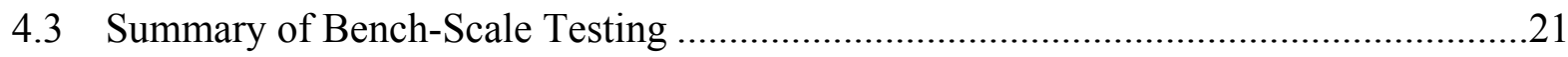

4.4 Boric Acid Addition Confirmation .....................................................................21

4.5 SRNL Calorimeter Results .....................................................................................2

4.6 Scale-up Testing at Gibson Pressure Grouting Service, Inc.....................................25

4.6.1 Scale-up Test Results .......................................................................................26

4.7 Blended Calcium Aluminate - Calcium Sulfate Grout Mineralogy

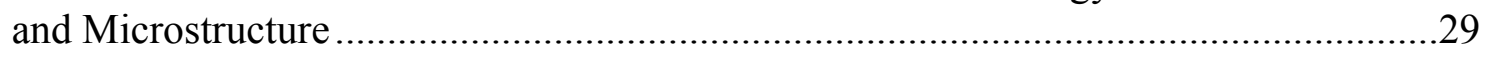

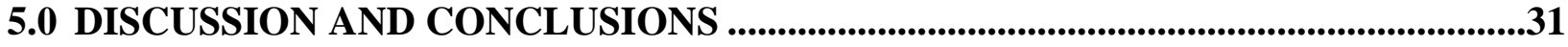

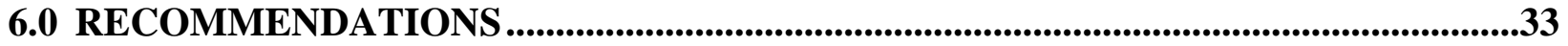

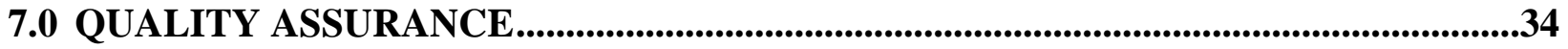

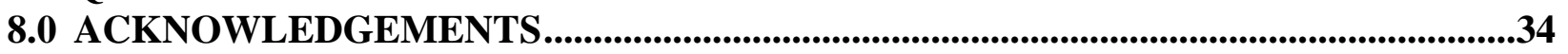

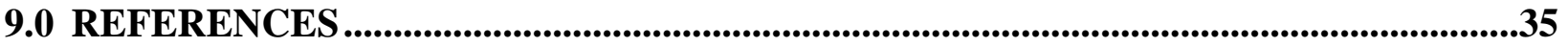




\section{LIST OF TABLES}

Table 1-1. SRS ISD Reactor Vessel grout fill requirements.

Table 3-1. Issues and tests for evaluating calcium aluminate - calcium hemihydrate cements for flowable, mass pour grout applications.

Table 3-2. Materials used in laboratory and scale-up testing.*

Table 4-1. Summary of first and second tier screening for blended Ciment Fondu ${ }^{\circledR}-$ Plaster of Paris mixes.

Table 4-2. Summary of set retarder screening for blended Ciment Fondu ${ }^{\circledR}-$ Plaster of Paris mixes.

Table 4-3. Summary of water reducing and high range water reducing admixture screening for blended Ciment Fondu ${ }^{B}$ - Plaster of Paris mixes.

Table 4-4. Summary of high range water reducing and viscosity modifying admixtures for blended CimentFondu ${ }^{\circledR}$ - Plaster of Paris mixes.

Table 4-5. Summary of alternative viscosity modifying admixtures for blended Ciment Fondu ${ }^{\circledR}$ - Plaster of Paris mixes

Table 4-6. Summary of bench scale-up testing with citric acid.

Table 4-7. Summary of bench scale-up testing with boric acid.

Table 4-8. Summary of boric acid dose results.

Table 4-9. Calorimeter Mixes with Boric Acid

Table 4-10. Blended calcium aluminate - calcium sulfate cement grout recommended for scale-up and mock-up testing.

Table 5-1. Blended calcium aluminate - calcium sulfate grouts developed for P-Reactor vessel ISD.

Table 5-2. Properties of P-Reactor vessel blended calcium aluminate - calcium sulfate cement grouts

Table 6-1. Recommended blended calcium aluminate - calcium sulfate cement grout for P-Reactor vessel ISD. 


\section{LIST OF FIGURES}

Figure 1-1. Isometric view of the SRS P-Reactor [Vrettos, 2009] ....................................... 2

Figure 1-2. P-Reactor cross section [Vrettos, 2009] .................................................... 2

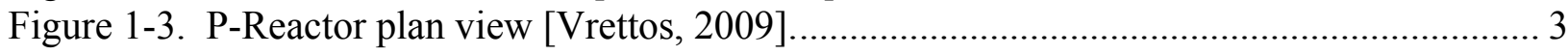

Figure $3-1$. Hobart planetary mixer used for preparing samples. .......................................... 9

Figure 3-2. Visual observation of liquid phase segregation. ............................................... 9

Figure 3-3. ASTM D-6103 Flow Test and example of self-leveling grout. Modified test used smaller $(2 \times 4$ inch) cylinders.

Figure 3-4. Static working time test samples. Modified after ASTM D-6103 by performing at selected time intervals.

Figure 3-5. Compressive strength cubes prepared per ASTM C-942 prior to stripping molds... 10

Figure 3-6. ASTM C-39 Compression Test Apparatus..................................................... 10

Figure 3-7. ASTM C-939 flow cone test. ......................................................................... 10

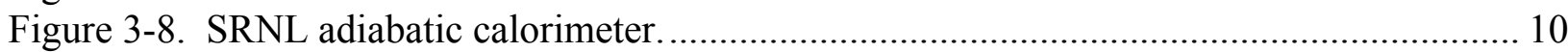

Figure 4-1. Bench scale-up flow test for citric acid formulation. Progressive filling of container with obstructions (a to c). Progressive filling of obstructions with $3 / 16$ inch diameter holes (d to e) and $3 / 8$ inch wide slit (f).

Figure 4-2. Bench scale-up flow test for boric acid formulation. Flowable grout placed in a container with obstructions (a). Grout flowing into obstructions via 3/16 inch diameter holes (b).

Figure 4-3. Static flow test results for Mix FG-26I (boric acid mix) per modified

ASTM D-6103. Initial spread and spread after increasing times under static conditions.

Figure 4-4. Adiabatic calorimeter result for selected mixes with different binder amounts and boric acid set retarder concentrations.

Figure 4-5. Scale-up Test. (a) Mixing Evaluation, (b and c) Re-circulating loop and Pump test, (d) Field static gel time test, (e) Semi-adiabatic temperature rise monolith, and (f) Mock-up vessel flow evaluation.

Figure 4-6. Blended calcium aluminate - calcium sulfate cement grout semi-adiabatic temperature results for one cubic yard monolith prepared on 9-2-2010 ................ 28

Figure 4-7. Core drilling of the monolith. Samples used for XRD, SEM and strength............ 29

Figure 4-8. X-ray diffraction of hydrated blended calcium aluminate - calcium sulfate (2:1 by weight) cement grout. Ettringite is the only cementitious crystalline phase. Quartz sand, the fine aggregate in the grout is also present in the sample analyzed.

Figure 4-9. Microstructure of the hydrated blended calcium aluminate - calcium sulfate cement-based grout. 


\section{LIST OF ACRONYMS AND ABREVIATIONS}

$\begin{array}{ll}\text { ALARA } & \text { As Low as Reasonably Achievable } \\ \text { ARRA } & \text { American Reinvestment and Recovery Act } \\ \text { ASTM } & \text { American Society for Testing \& Materials } \\ \text { CAC } & \text { Calcium aluminate cement } \\ \text { CACS } & \text { Calcium aluminate - Calcium sulfate (hemihydrate) } \\ \text { DOE } & \text { Department of Energy } \\ \text { EARAIP } & \text { Early Action Remedial Action Implementation Plan } \\ \text { E\&CPT } & \text { Environmental and Chemical Processing Technology } \\ \text { EDX } & \text { Energy Dispersive X-ray } \\ \text { EM } & \text { Environmental Management } \\ \text { ES\&BT } & \text { Environmental Sciences and Bio Technology } \\ \text { HRWR } & \text { High Range Water Reducer } \\ \text { ISD } & \text { In-Situ Decommissioning } \\ \text { LLC } & \text { Limited Liability Corporation } \\ \text { PAOU } & \text { P-Area Operable Unit } \\ \text { PS\&E } & \text { Process Science and Engineering } \\ \text { RH } & \text { Relative Humidity } \\ \text { RV } & \text { Reactor Vessel } \\ \text { SDD } & \text { Site Deactivation and Decommissioning } \\ \text { SEM } & \text { Scanning Electron Microscope } \\ \text { SRNL } & \text { Savannah River National Laboratory } \\ \text { SRNS } & \text { Savannah River Nuclear Solutions } \\ \text { SRS } & \text { Savannah River Site } \\ \text { STI } & \text { Scientific Technical Information } \\ \text { STR } & \text { Subcontract Technical Representative } \\ \text { TAR } & \text { Technical Assistance Request } \\ \text { TT / QAP } & \text { Technical Task and Quality Assurance Plan } \\ \text { TTR } & \text { Technical Task Request } \\ \text { UPV } & \text { Ultrasonic Pulse Velocity } \\ \text { VMA } & \text { Viscosity Modifying Admixture } \\ \text { WSRC } & \text { Washington Savannah River Company } \\ \text { XRD } & \text { X-ray diffraction } \\ & \\ & \end{array}$

\section{Abbreviations}

$\begin{array}{ll}\mathrm{C} & \text { Celcius } \\ \mathrm{cc} & \text { cubic centimeter } \\ \text { cu ft } & \text { cubic foot } \\ \text { cyd } & \text { cubic yard } \\ \mathrm{ft} & \text { feet } \\ \mathrm{g} & \text { gram } \\ \mathrm{gal} & \text { gallon } \\ \text { gpm } & \text { gallon per minute } \\ \mathrm{hr} & \text { hour } \\ \mathrm{lbs} & \text { pounds } \\ \mathrm{NM} & \text { not measured } \\ \mathrm{min} & \text { minute } \\ \mathrm{psi} & \text { pounds per square inch } \\ \mathrm{s} & \text { seconds } \\ \mathrm{wt} & \text { weight (wt.\% = weight percent) }\end{array}$




\subsection{INTRODUCTION}

\subsection{Objective}

The objective of this report is to document laboratory testing of blended calcium aluminate calcium hemihydrate grouts for P-Reactor vessel in-situ decommissioning. ${ }^{4}$ Blended calcium aluminate - calcium hemihydrate cement-based grout was identified as candidate material for filling (physically stabilizing) the 105-P Reactor vessel (RV) because it is less alkaline ${ }^{5}$ than portland cement-based grout which has a $\mathrm{pH}$ greater than 12.4. In addition, blended calcium aluminate - calcium hemihydrate cement compositions can be formulated such that the primary cementitious phase is a stable crystalline material. ${ }^{6}$ A less alkaline material $(\mathrm{pH} \leq 10.5)$ was desired to address a potential materials compatibility issue caused by corrosion of aluminum metal in highly alkaline environments such as that encountered in portland cement grouts [Wiersma, 2009a and b, Wiersma, 2010, and Serrato and Langton, 2010]. Information concerning access points into the P-Reactor vessel and amount of aluminum metal in the vessel is provided elsewhere [Griffin, 2010, Stefanko, 2009 and Wiersma, 2009 and 2010, Bobbitt, 2010, respectively]. Radiolysis calculations are also provided in a separate document [Reyes-Jimenez, 2010].

This work supports scope identified and authorized in TAR-SDD-2008-00133 [Musall, 2009], TAR-SDD-2009-00231 [Musall, 2010], and TT/QAP, SRNL-RP-2009-01248 [Stefanko, 2009b]. This work supports the SRS Reactor Facilities In-Situ Decommissioning (ISD) Projects and was funded by the American Recovery and Reinvestment Act.

\subsection{P-Reactor Vessel In-Situ Decommissioning}

\subsubsection{P-Area Reactor Vessel Description}

SRNS committed to the Department of Energy to fill the reactor vessels in 105-P and 105-R with grout to the extent practicable as part of the SRS Reactor Facilities In-Situ Decommissioning Projects. The main tank (referred to as the reactor vessel) in each reactor was constructed of 304 stainless steel and is 16 feet in diameter and 16 feet in height. The tank is capped with Tube Sheets on the top and bottom which are approximately four and 3.5 feet in height, respectively. The top tube sheet is covered with a Plenum approximately 2 feet high. A steel shell around the reactor vessel forms a Thermal Shield around the tank with a Cooling Annulus of about 21 inches wide. The steel shell is surrounded by a five foot thick Biological Shield consisting of reinforced

\footnotetext{
${ }^{4}$ SRNS/SDD-Engineering made the decision to fill the R-Reactor vessel with a portland cement based grout based on the amount of aluminum metal estimated to have been left in the vessel [Serrato, 2010 and Wiersma, 2010].

${ }^{5}$ Water in contact with calcium aluminate cement phases has a $\mathrm{pH}$ ranging from 10 to 11 depending on impurities. Water in contact with hydrated calcium sulfate compounds such as calcium sulfate hemihydrate has a $\mathrm{pH}$ between 5.5 to $8+$ depending on impurities. Consequently mixtures of these ingredients which hydrate to form stable cementitious materials were investigated for the P-Reactor fill application.

${ }^{6}$ Thermodynamically stable cementitious reaction products are an important feature of a durable material. Unstable reaction products that are initially cementitious but undergo phase changes and associated volumetric changes over time (densification or expansion) do not produce durable materials.
} 
concrete. These features, except for the biological shield, are illustrated for P-Reactor vessel in isometric view and cross-section in Figures 1-1 and 1-2, respectively [Vrettos, 2009]. A top view of the P-Reactor plenum is shown in Figure 1-3. The strategy for filling the P-Reactor vessel is to pull plugs in 3 to 8 permanent sleeves along the circumference of the vessel and to use these positions as grout entry and vent points in the vessel [Griffin, 2010a]. The details of the connection between the grout hose and reactor vessel were finalized after scale-up testing and final design of the grout placement [Griffin, 2010a].

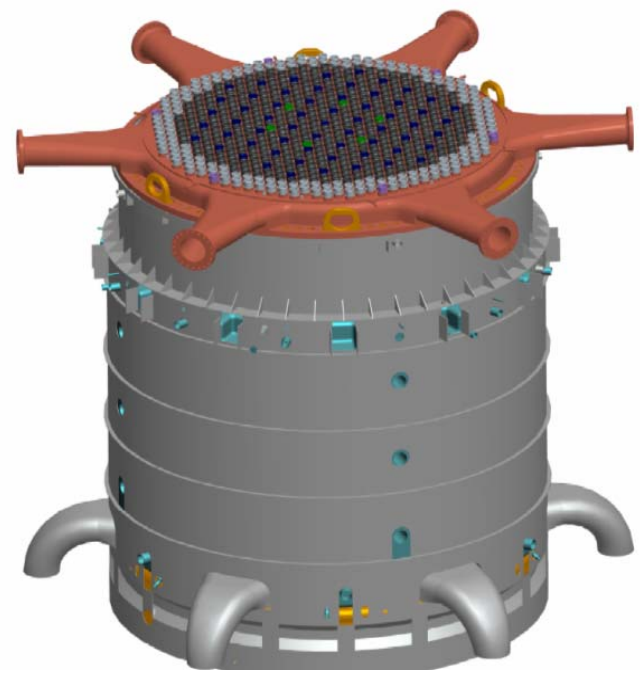

Figure 1-1. Isometric view of the SRS P-Reactor [Vrettos, 2009].

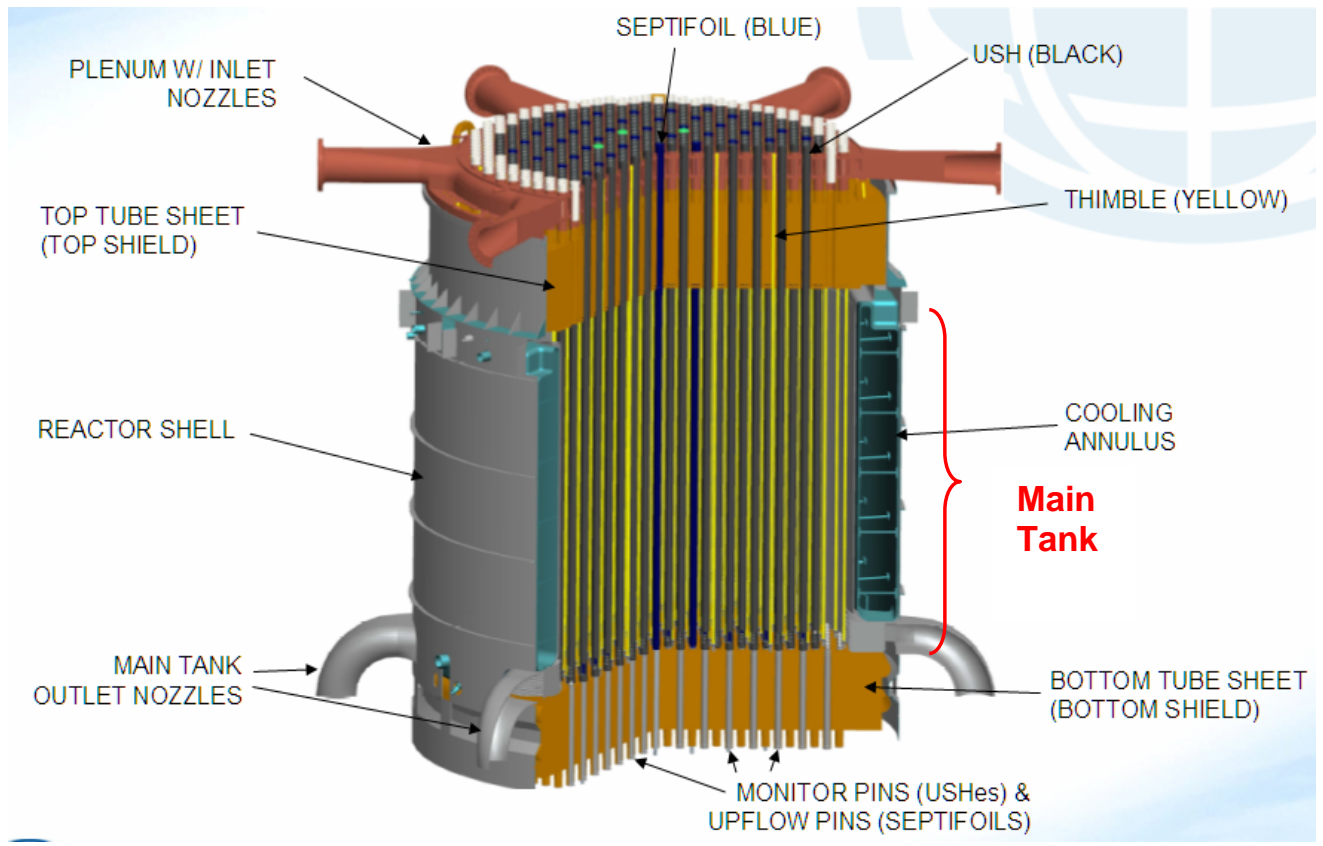

Figure 1-2. P-Reactor cross section [Vrettos, 2009]. 


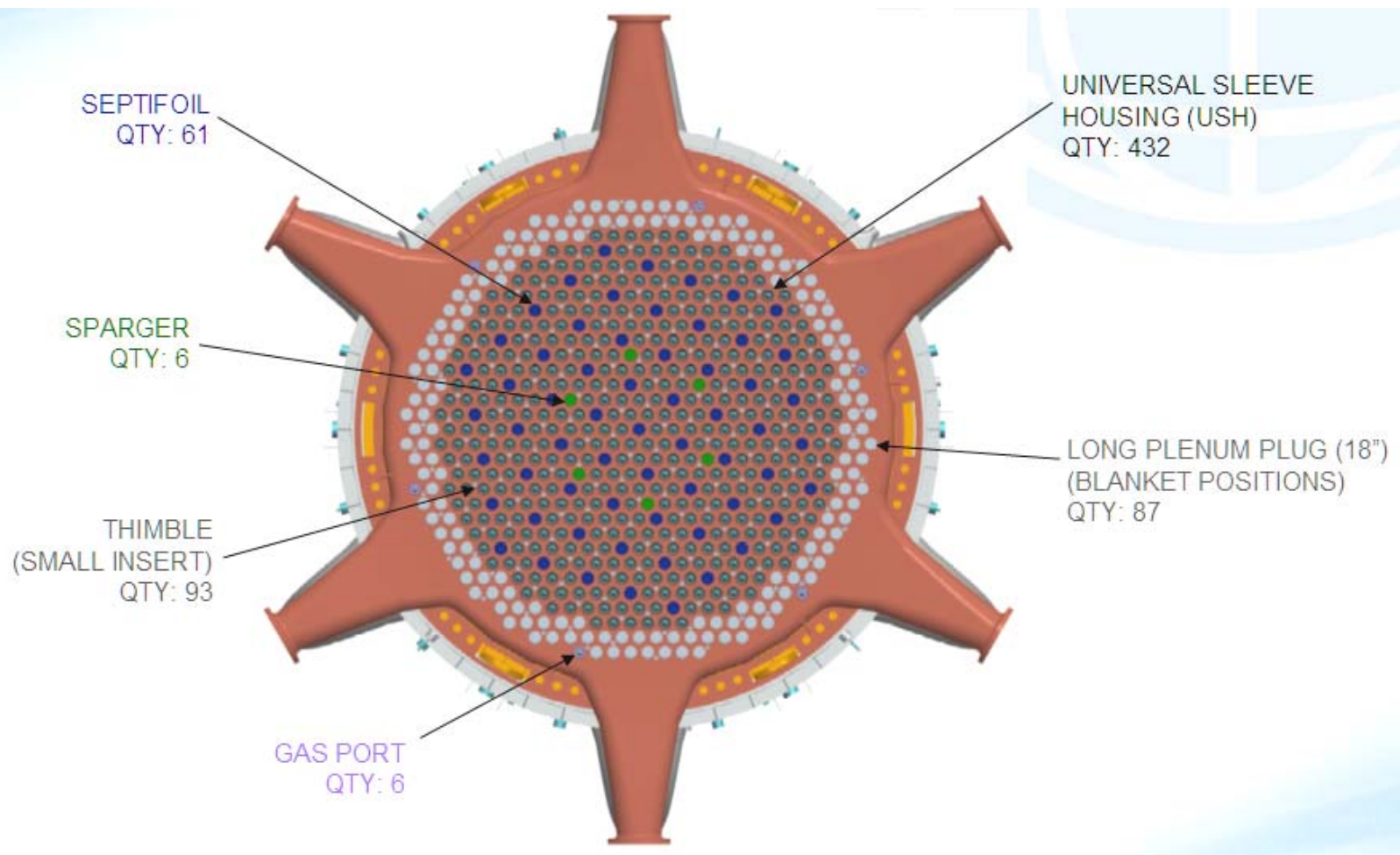

Figure 1-3. P-Reactor plan view [Vrettos, 2009].

\subsubsection{In-Situ Decommissioning Fill Requirements}

The in-situ decommissioning requirements for filling the RV are listed below [PAOU, 2008]:

- Fill the RV to the maximum extent practical with a stabilizing grout/fill material.

- Fill material shall have a minimum compressive strength of $50 \mathrm{psi}$ and be non-corroding. An additional minimum requirement is that the fill contain an integral water proofing agent [Blankenship, 2009].

Based on an initial understanding of the RV configuration and field conditions, the requirements were restated as engineering property attributes and criteria and are listed in Table 1-1. 
SRNL-STI-2010-00427 Revision 0

March 10, 2011

Page 4 of 37

Table 1-1. SRS ISD Reactor Vessel grout fill requirements.

\begin{tabular}{|c|c|c|}
\hline Property & Requirement & Comments \\
\hline \multicolumn{3}{|l|}{ Slurry Properties (Fresh Properties) } \\
\hline $\mathrm{pH}$ & $\leq 10.5$ & $\begin{array}{l}\text { Aluminum corrosion rate } \\
\text { [Weirsma, 2010] }\end{array}$ \\
\hline Viscosity & $<350$ cp (desirable) & $\begin{array}{l}\text { Pumpable slurry ( } 400 \mathrm{ft} \text { through } 1 \text { to } \\
2 \text { inch hose) }\end{array}$ \\
\hline Yield Stress & pumpable & $\begin{array}{l}\text { As low as possible without } \\
\text { segregation }\end{array}$ \\
\hline Self leveling & Yes & $\begin{array}{l}\text { Reactor vessel entry points for } \\
\text { vibrating the grout to achieve } \\
\text { consolidation are limited }\end{array}$ \\
\hline Flow Cone & $<50 \mathrm{~s}$ & Flowable, self leveling (desired) \\
\hline Static Working Time & $\sim 30$ minutes & $\begin{array}{l}\text { Grout needs to remain fluid as the } \\
\text { velocity decreases (to zero) as a } \\
\text { function of distance from the discharge } \\
\text { point in the reactor vessel }\end{array}$ \\
\hline Dynamic Working Time & $>60$ minutes & $\begin{array}{l}\text { Longer is desired for recovery from } \\
\text { upset conditions }\end{array}$ \\
\hline Set Time & $2 \mathrm{hr}$ to $24 \mathrm{hr}$ desired & Sufficient time to prevent settling \\
\hline Density (wet unit weight) & 80 to $140 \mathrm{lbs} / \mathrm{cu} \mathrm{ft}$ & $\begin{array}{l}\text { Pumpable through } 1-2 \text { inch ID hose } \\
\text { Non cellular, "normal" weight material }\end{array}$ \\
\hline Bleed water & None & Physically stable slurry is required \\
\hline Segregation & None & Physically stable slurry is required \\
\hline Maximum particle size & $3 \mathrm{~mm}$ maximum & $\begin{array}{l}<0.5 \mathrm{~mm} \text { may be necessary pending } \\
\text { further understanding of reactor } \\
\text { vessel construction and test results }\end{array}$ \\
\hline \multicolumn{3}{|l|}{ Cured Properties } \\
\hline \multicolumn{3}{|l|}{ Compressive Strength } \\
\hline 3 days & 200 psi minimum & \multirow{2}{*}{$\begin{array}{l}50 \text { psi required in regulatory } \\
\text { documentation }\end{array}$} \\
\hline 28 days & 200 psi minimum & \\
\hline Adiabatic temperature rise & $<60^{\circ} \mathrm{C}$ & $\begin{array}{l}\text { As low as possibly and still achieve } \\
\text { compressive strength. }\end{array}$ \\
\hline Maximum placement temperature & $35^{\circ} \mathrm{C}$ & Suitable for mass pours \\
\hline
\end{tabular}

Pour schedules, lift heights, and total time to fill a reactor vessel were also important considerations in formulation development. Minimizing the number of lifts (start and stop cycles) and minimizing the total fill time impact the ISD project (ALARA, cost, schedule, waste generation). 


\subsection{CALCIUM ALUMINATE CEMENT SYSTEMS}

\subsubsection{Calcium Aluminate Cements}

Commercially available calcium aluminate cements (CAC) were initially considered as the binder for a low $\mathrm{pH}$ reactor fill grout because they buffer the $\mathrm{pH}$ of water between 9 and 10 which was one of the requirements for P-Reactor Vessel grout [Weirsma, 2009a and b and Weirsma, 2010]. ${ }^{7}$ However, the hydrated calcium aluminate phases that initially form under ambient conditions when these cements come in contact with water, $\mathrm{CaO} \cdot \mathrm{Al}_{2} \mathrm{O}_{3} \cdot 10 \mathrm{H}_{2} \mathrm{O}$ and $2 \mathrm{CaO} \cdot \mathrm{Al}_{2} \mathrm{O}_{3} \cdot 8 \mathrm{H}_{2} \mathrm{O}$, are thermodynamically unstable and convert over time to a non cementitious hydrogarnet, stratlingite $\left(3 \mathrm{CaO} \cdot \mathrm{Al}_{2} \mathrm{O} \cdot 6 \mathrm{H}_{2} \mathrm{O}\right)$, which is the only stable hydrated phase in the system $\mathrm{CaO}-\mathrm{Al}_{2} \mathrm{O}_{3}-\mathrm{H}_{2} \mathrm{O}$. This phase conversion is accompanied by the loss of strength and cementitious properties and is the reason calcium aluminate cements are not used as binders for ambient temperature applications.

\subsubsection{Calcium Sulfo-aluminate Cement}

Commercially available calcium sulfo-aluminate cement (CSAC) was also considered as a potential binder for a low $\mathrm{pH}$ reactor fill grout. ${ }^{8}$ This cementitious system was described in the early 1900's and developed into commercial products in China in the 1970's. The primary clinker compounds (produced in the cement kiln) are yeelimite $\left(\mathrm{Ca}_{4} \mathrm{Al}_{6} \mathrm{O}_{12}\left(\mathrm{SO}_{4}\right)\right)$, belite $\left(\mathrm{Ca}_{2} \mathrm{SiO}_{4}\right)$, and ferrite phase $\left(\mathrm{C}_{4} \mathrm{AF}\right)$ (listed in decreasing abundance). These cements are typically inter ground with additional calcium sulfate compounds ${ }^{9}$ to achieve the desired final reaction product which is ettringite plus alumina gel (non crystalline aluminum hydroxide). The majority of the CSAC is produced in China where it is used in various types of construction and for producing rapid setting cements. The principle matrix phase in hydrated CSAC is ettringite, $\mathrm{Ca}_{6} \mathrm{Al}_{2}\left(\mathrm{SO}_{4}\right)_{3}(\mathrm{OH})_{12} \cdot 26\left(\mathrm{H}_{2} \mathrm{O}\right)^{10}$. Non crystalline calcium- silica hydrates $(\mathrm{C}-\mathrm{S}-\mathrm{H})$ and calcium aluminum / iron monosulfate phases along with a significant amount of unreacted clinker are also reported in typical formulations [Glasser and Zhang, 2001]. The conversion reactions which occur in hydrated calcium aluminate cement do not occur in CSAC at ambient conditions.

Calcium sulfo-aluminate cements and blends of calcium sulfo-aluminate cement and gypsum have been evaluated for stabilization of heavy metals [Peysson, et al., 2005] with good retention demonstrated for multivalent metals. Calcium sulfo-aluminate cements have also been evaluated as candidates for waste encapsulation [Zhou, et. al., 2006]. Fluid grouts with pHs between 10.5

\footnotetext{
${ }^{7}$ These types of cements are typically used in high-temperature applications as refractory cements. Blends of these cements with portland cement and gypsum are used for ambient temperature applications as leveling compounds. However commercial formulations are designed for dry indoor conditions.

${ }^{8}$ About $40 \%$ less $\mathrm{CO} 2$ is generated by the production of CSACs compared to portland cement and it can be produced at temperatures 200 to $300 \mathrm{C}$ lower that portland cement.

${ }^{9} 16$ to 25 weight percent $\mathrm{CaSO}_{4}$ is typical. The amount depends on the intended end use. Expansive formulations are also produced by blending the cement with $\mathrm{Ca}(\mathrm{OH})_{2}$ which results in an ettringite microstructure that causes expansion or shrinkage compensation depending on the amount.

${ }^{10} \mathrm{C}_{3} \mathrm{~A} \cdot 3 \mathrm{CS} \cdot 32 \mathrm{H}$ is an alternative representation representing $\mathrm{CaO}$ as $\mathrm{C}, \mathrm{Al}_{2} \mathrm{O}_{3}$ as $\mathrm{A}, \mathrm{SO}_{4}$ as $\boldsymbol{S}$, and $\mathrm{H}$ as $\mathrm{H}_{2} \mathrm{O}$.
} 
and 11 have been prepared from blends of Rockfast ${ }^{\circledR}$ (LaFarge product) calcium sulfo-aluminate cement and gypsum and tested for encapsulation of reactive metals [Hays and Godfrey, 2007].

\subsubsection{Blended Calcium Aluminate - Calcium Hemihydrate Cement}

Blends of calcium aluminate cement and other cements such as, belite cement, gypsum, portland cement + gypsum, slag cement, slag cement + sodium carbonate, calcium carbonate, and other reactive ingredients such as micro-silica and sodium silicate have been tested for various applications and are summarized elsewhere [Odler, 2000]. Given the acceptable pHs of calcium aluminate cements in contact with water (9 to 10) and gypsum cements in equilibrium with water $(\sim 6)$, blends of calcium aluminate cement and calcium hemihydrate $\left(\mathrm{CaSO}_{4} \bullet \frac{1}{2} \mathrm{H}_{2} \mathrm{O}\right)$ were identified as potential candidates for the P-Reactor vessel grout.

Commercially available products that are blends of calcium aluminate cement and other materials were reviewed for suitability as reactor vessel fill materials. Pumpable, flowable, self-leveling, gypsum-based slurries are used as interior floor leveling materials, but all of the materials researched contained some portland cement which results in $\mathrm{pHs}$ of $\sim 12.4$.

The approach was to identify and test blends of commercially available calcium aluminate cements and calcium sulfate hemihydrate (Plaster of Paris) with the objective of forming ettringite as the primary cementitious phase. These ingredients were proportioned to provide enough calcium sulfate to form ettringite as the primary cementitious phase as the result of reaction with the calcium aluminate phases in the CAC. Excess aluminum forms alumina gel. See Equation 1.

\section{Equation 1. $3 \mathrm{CaAlO}_{4}+3 \mathrm{CaSO}_{4}{ }^{-1 / 2} \mathrm{H}_{2} \mathrm{O}+\mathrm{XH}_{2} \mathrm{O} \longrightarrow \mathrm{Ca}_{6} \mathrm{Al}_{2}\left(\mathrm{SO}_{4}\right)_{3}(\mathrm{OH})_{12} \bullet 26\left(\mathrm{H}_{2} \mathrm{O}\right)+\mathrm{Al}(\mathrm{OH})_{3}$}

The Plaster of Paris used in this testing was obtained from US Gypsum Company, Chicago, IL. Two calcium aluminate cements were initially tested, Ciment Fondu ${ }^{\circledR}$ and Secar ${ }^{\mathbb{R}} 41$. Both products are manufactured by Kerneos Aluminate Technologies, Chesapeake, VA. The primary calcium aluminate phase in both cements is $\mathrm{CaAlO}_{4}{ }^{11}$ Ciment Fondu ${ }^{\circledR}$ was selected for the blends because it contains a small amount of dicalcium silicate which contributes to the microstructure and strength of the cured material. It was also less expensive than Secar ${ }^{\circledR} 41$ which does not contain dicalcium silicate. In addition, inclusion of $\mathrm{KIM}^{\circledR} 301$, an integral waterproofing reagent marketed by Kryton International Inc, was specified by SDD / SRNS [Blankenship, 2009] as an ingredient in the reactor fill grout.

\subsection{Blended Calcium Aluminate - Calcium Sulfate Hemihydrate Cement Grouts}

In order to reduce the heat generated from chemical reactions between the blended cement and water, chemically inert fillers were added to produce P-Reactor vessel fill grouts. Class F fly ash and quartz sand were selected as inert filler based on testing to develop a magnesium phosphate

\footnotetext{
${ }^{11} \mathrm{Ciment}$ Fondu ${ }^{\circledR}$ also contains $12 \mathrm{CaO} \cdot 7 \mathrm{Al}_{2} \mathrm{O}_{3}, 2 \mathrm{CaO} \cdot \mathrm{SiO}_{2}$ and $4 \mathrm{CaO} \cdot \mathrm{Al}_{2} \mathrm{O}_{3} \cdot \mathrm{Fe}_{2} \mathrm{O}_{3}$. Secar ${ }^{\circledR} 41$ also contains $2 \mathrm{CaO} \cdot \mathrm{Al}_{2} \mathrm{O}_{3} \cdot \mathrm{SiO}_{2}$.
} 
cement grout for filling the SRS reactor vessels ${ }^{12}$ [Stefanko, Langton, and Singh, 2011]. Two size fractions of quartz sand, ASTM C-404 masonry sand and ASTM C-637 Grading 2 sand, were tested. Because the P-Reactor vessel contains a dense array of flow obstructions (universal sleeve housings, thimbles, septifoils, spargers) coarse aggregate (3/8 inch granite gravel) was not included in the grout mix design.

Details of the proposed scale-up testing activities are provided elsewhere, G-SOW-G-00121 [Griffin, Langton and Stefanko, 2010].

12 This combination of inert fillers provides a bimodal particle size distribution that contributes to achieving the desired flow properties, i.e., reducing bleed while producing highly flowable material. 


\subsection{EXPERIMENTAL METHOD}

\subsection{Test Methods}

Material properties and test methods for evaluating these properties are listed in Table 3-1. Examples of flowable fill mixing and testing are provided in Figures 3-1 to 3-8.

Table 3-1. Properties and test methods for P-Reactor vessel fill grout.

\begin{tabular}{|c|c|}
\hline Properties & Test Method \\
\hline Spread / Flow & $\begin{array}{l}\text { Modified ASTM D-6103 (Used } 2 \times 4 \text { inch cylinder rather than } 3 \times \\
6 \text { inch cylinder) }\end{array}$ \\
\hline $\begin{array}{l}\text { Static Working Time } \\
\text { Static Gel Time } \\
\text { (Screening) }\end{array}$ & $\begin{array}{l}\text { Modified ASTM D-6103 } \\
\text { Multiple } 2 \text { x } 4 \text { inch cylinders filled to } 3 \text { inch height at time zero. } \\
\text { Spread measured selected time intervals } \\
\text { Spread diameter reported }\end{array}$ \\
\hline $\begin{array}{l}\text { Dynamic Working Time } \\
\text { (Screening) }\end{array}$ & $\begin{array}{l}\text { Initial measurement same as Modified ASTM D-6103 } \\
\text { Repeat Modified ASTM D-6103 using material recovered from } \\
\text { test and returned to mixer for specified times }\end{array}$ \\
\hline Flow & ASTM C-939 (flow cone) \\
\hline $\begin{array}{l}\text { Dynamic Working Time } \\
\text { Using Flow Cone }\end{array}$ & $\begin{array}{l}\text { Initial measurement same as Modified ASTM C-939. } \\
\text { Repeat Modified ASTM C-939 using material recovered from test } \\
\text { and returned to mixer for specified times. Repeat Modified ASTM }\end{array}$ \\
\hline $\begin{array}{l}\text { Set Time from } \\
\text { Calorimeter }\end{array}$ & $\begin{array}{l}\text { Determined from calorimeter data (acceleration in reaction rate) } \\
\text { SRNL test method }\end{array}$ \\
\hline $\begin{array}{l}\text { Set Time } \\
\text { (Screening) }\end{array}$ & $\begin{array}{l}\text { Appearance of a rigid solid } \\
\text { SRNL Ultrasonic Pulse Velocity (UPV) test method }\end{array}$ \\
\hline $\begin{array}{l}\text { Exothermic Reaction } \\
\text { (adiabatic conditions) }\end{array}$ & $\begin{array}{l}\text { SRNL adiabatic calorimeter method } \\
\text { SRNL test method }\end{array}$ \\
\hline Specific Heat & Energy balance method \\
\hline Thermal Conductivity & Transient conduction calculation method \\
\hline Bleed (Segregation) & $\begin{array}{l}\text { Modified ASTM C-232 } \\
\text { Estimate amount of liquid segregation after one hour }\end{array}$ \\
\hline Compressive Strength & $\begin{array}{l}\text { ASTM C-39 ( } 2 \text { x } 4 \text { inch cylinders }) \\
\text { ASTM C-942 ( } 2 \text { inch cubes) } \\
\text { ASTM C-39 (compression test cylinders) } \\
\text { ASTM C-109 (compression test cubes) }\end{array}$ \\
\hline Expansion (Screening) & Visual Examination of set material. \\
\hline Chemical Compatibility & $\begin{array}{l}\text { Slurry } \mathrm{pH}: \mathrm{pH} \text { paper } \\
\text { Cured material in contact with water: SRNL pH Test Method }\end{array}$ \\
\hline
\end{tabular}




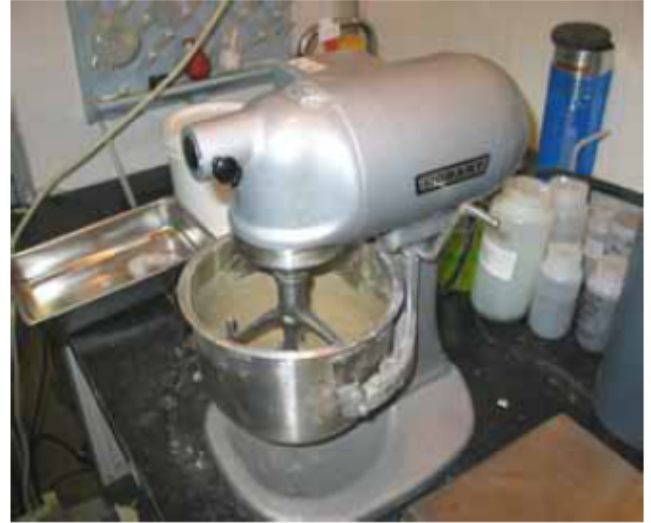

Figure 3-1. Hobart planetary mixer used for preparing samples.

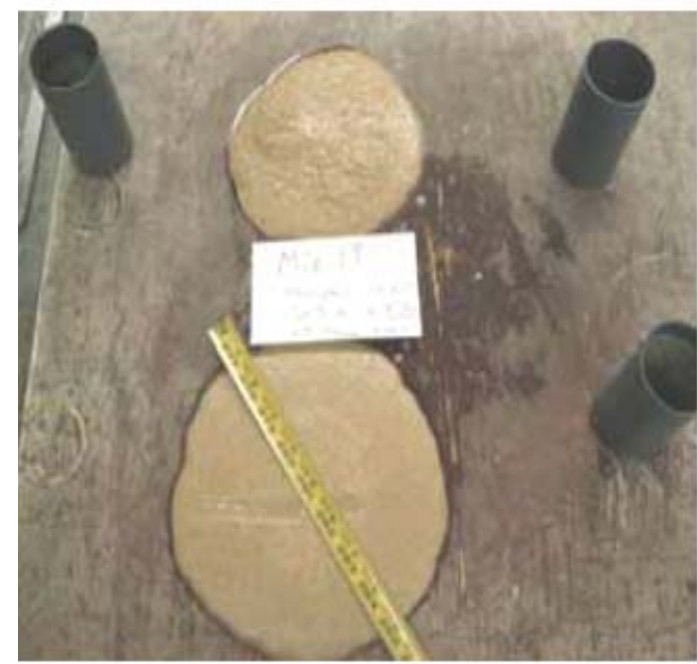

Figure 3-3. ASTM D-6103 Flow Test and example of self-leveling grout. Modified test used smaller ( 2 x 4 inch) cylinders.

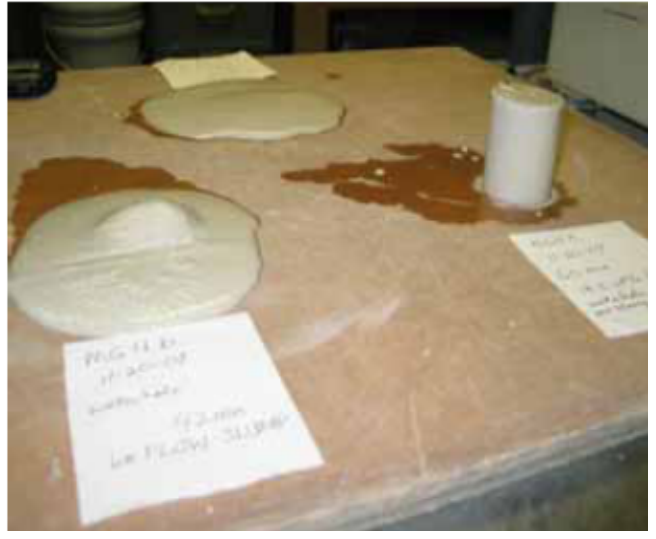

Figure 3-2. Visual observation of liquid phase segregation.

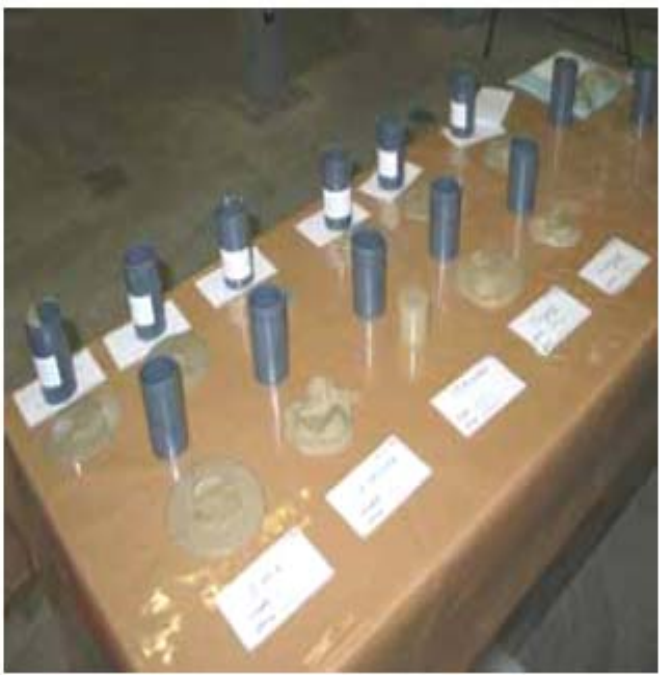

Figure 3-4. Static working time test samples. Modified after ASTM D-6103 by performing at selected time intervals. 
Page 10 of 37
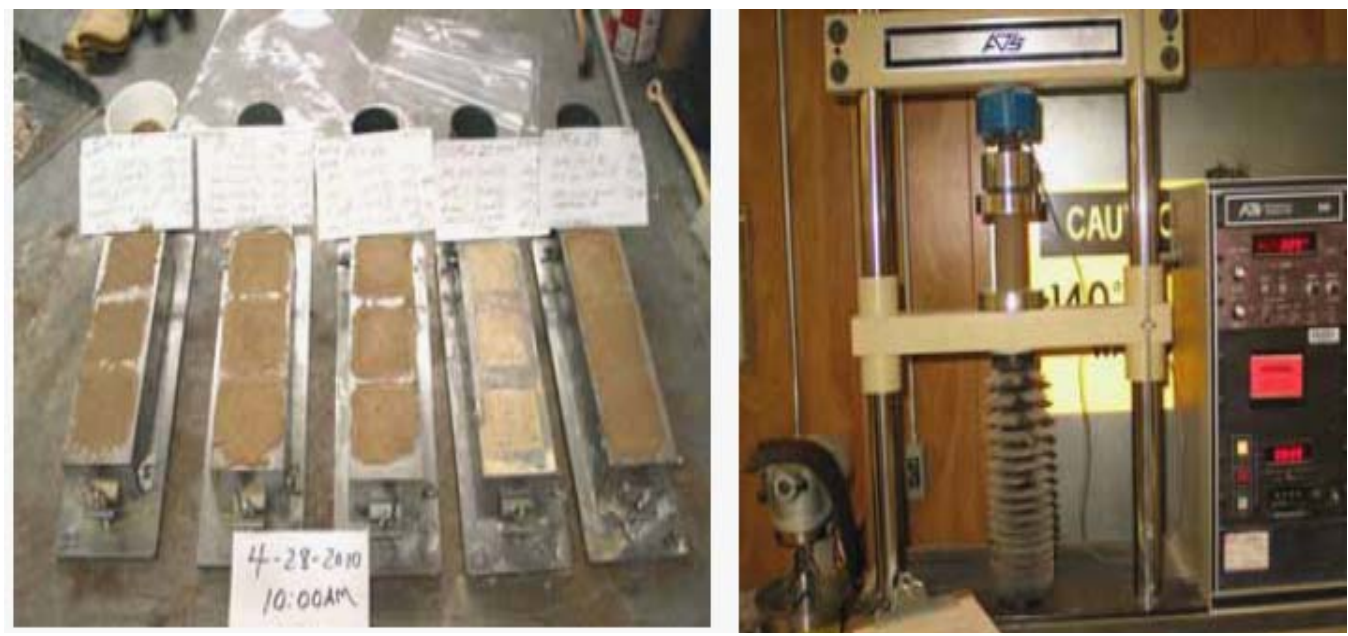

Figure 3-5. Compressive strength cubes prepared per ASTM C-942 prior to stripping molds.

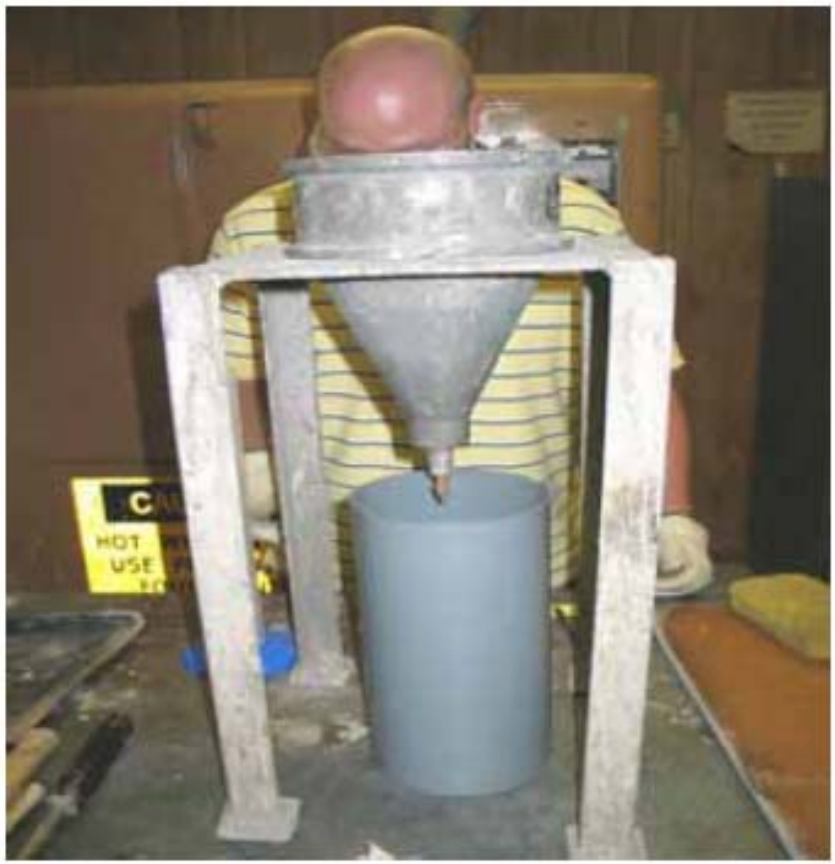

Figure 3-7. ASTM C-939 flow cone test.
Figure 3-6. ASTM C-39 Compression Test Apparatus.

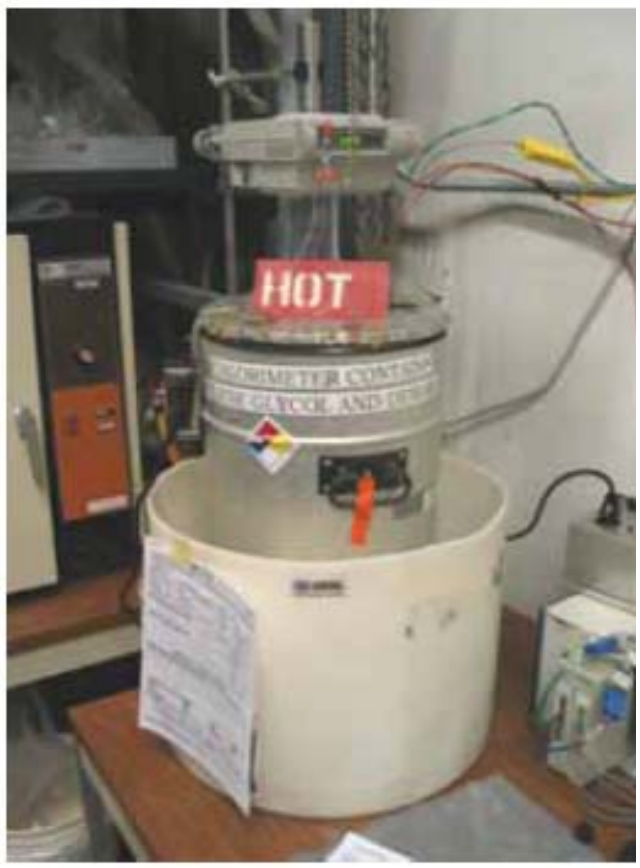

Figure 3-8. SRNL adiabatic calorimeter. 


\subsection{Materials and Reagents}

Materials used to formulate reactor vessel grouts and material suppliers are provided in Table 3-2.

Table 3-2. Materials used in laboratory and scale-up testing.*

\begin{tabular}{|c|c|}
\hline Material & Supplier \\
\hline Secar $^{(B)} 41$ & $\begin{array}{l}\text { Kerneos Aluminate Technologies, Chesapeake, VA } \\
\text { www.kerneosinc.com }\end{array}$ \\
\hline Ciment Fondu $^{(B)}$ & $\begin{array}{l}\text { Kerneos Aluminate Technologies, Chesapeake, VA } \\
\text { www.kerneosinc.com }\end{array}$ \\
\hline Plaster of Paris (calcium sulfate hemihydrate) & US Gypsum Company, Chicago, IL \\
\hline \multicolumn{2}{|l|}{ Powder Filler } \\
\hline $\begin{array}{l}\text { Class F Fly Ash }(<3 \text { wt. \% carbon) } \\
\text { Wateree Plant, SC and Scherer Plant, GA }\end{array}$ & $\begin{array}{l}\text { SEFA Group, Lexington, SC 29073, 888.339.SEFA } \\
\text { and Boral Materials Technologies, Atlanta GA }\end{array}$ \\
\hline \multicolumn{2}{|l|}{ Sand Fillers } \\
\hline Masonry Sand ASTM C-404 & $\begin{array}{l}\text { SCMI (South Carolina Mineral Industry) } \\
\text { South Carolina Highway } 125 \text { Quarry }\end{array}$ \\
\hline Quartz Sand ASTM C-637 Grading \#2 & Standard Sand \& Silica Co., Davenport, FL \\
\hline \multicolumn{2}{|l|}{ Additives } \\
\hline \multicolumn{2}{|l|}{ Integral Water Proofing Reagent } \\
\hline $\mathrm{KIM}^{\circledR} 301$ & Kryton International Inc., www.kryton.com \\
\hline \multicolumn{2}{|l|}{ Set Retarders } \\
\hline Boric Acid Technical grade, $\mathrm{H}_{3} \mathrm{BO}_{3}$ & $\begin{array}{l}\text { Reagents Inc. Charlotte, } \mathrm{NC}, 704-554-7474 \\
\text { Alfa Aesar }{ }^{\circledR} \text { www.alfa.com }\end{array}$ \\
\hline Citric Acid Monohydrate & Fisher Scientific, Fair Lawn, NJ, www.fishersci.com \\
\hline Recover & \multirow{2}{*}{$\begin{array}{l}\text { W. R. Grace and Co., Cambridge, MA } \\
\text { www.na.graceconstruction.com }\end{array}$} \\
\hline Daratard 17 & \\
\hline Borax (sodium tetraborate) & Wal-Mart, www.20muleteamlaundry.com \\
\hline \multicolumn{2}{|l|}{ Viscosity Modifiers } \\
\hline Diutan Gum, KELCO-CRETE ${ }^{(B)}$ DG & CP Kelco/ Huber Co., www.cpkelco.com \\
\hline Cembinder $^{(B)} 8$ & \multirow{2}{*}{$\begin{array}{l}\text { EKA Chemicals, Inc., GreenBay, WI } \\
\text { www.colloidalsilica.com }\end{array}$} \\
\hline Cembinder $\left.{ }^{(}\right) 50$ & \\
\hline Bentonite (Prime-A-PAC) & $\begin{array}{l}\text { Enviro Systems, Inc., Smyrna, GA, www.envirosys.us } \\
770-333-0206\end{array}$ \\
\hline \multicolumn{2}{|l|}{ High Range Water Reducers } \\
\hline SIKA ViscoCrete ${ }^{\circledR} 2100$ & SIKA Corporation, Lyndhurst, NJ, usa.sika.com \\
\hline ADVA 408 & $\begin{array}{l}\text { W. R. Grace and Co., Cambridge, MA } \\
\text { www.na.graceconstruction.com }\end{array}$ \\
\hline \multicolumn{2}{|l|}{ Mid Range Water Reducers } \\
\hline Superplast 1000 & ICI, Miami FL (no longer in business) \\
\hline WRDA 35 & $\begin{array}{l}\text { W. R. Grace and Co., Cambridge, MA } \\
\text { www.na.graceconstruction.com }\end{array}$ \\
\hline Water & $\begin{array}{l}\text { SRS process water, } \\
\text { SRS chilled process water }\left(<10^{\circ} \mathrm{C}\right) \\
\text { Smyrna, GA domestic water }\end{array}$ \\
\hline
\end{tabular}

*Materials in italics were procured by Gibson's Pressure Grouting Services Inc. and used in the scale-up and vessel fill mock up testing. These materials were also used for the full-scale production of the grouts used for filling the PReactor Vessel. 


\subsection{RESULTS: BLENDED CALCIUM ALUMINATE - CALCIUM SULFATE CEMENT GROUT}

\subsection{Screening Mixes}

Initial screening of calcium aluminate and blended calcium aluminate - Plaster of Paris mixes was based on the $\mathrm{pH}$ of water in contact with the hydrated cements and the stability of hydrated phase assemblages. A pH of 9 to 10 was measured for water in contact with hydrated Secar ${ }^{\circledR} 41$. A pH of 11 was measured for water in contact with hydrated Ciment Fondu ${ }^{\circledR}$. However, Secar ${ }^{\circledR} 41$ and Ciment Fondu ${ }^{\circledR}$, calcium aluminate cements, both have initial hydrated phase assemblages that are known to undergo a conversion with time and temperature [Older, 2000] and [Taylor, 1997]. Consequently neither of these materials met the material stability requirement in Table 1-1.

Blends of calcium aluminate cements and Plaster of Paris were prepared and evaluated by the same criteria. The blends were proportioned to result in ettringite as the stable hydration product. The $\mathrm{pHs}$ of water in contact with the hydrated blended formulations were 9 to 10 . The Ciment Fondu $^{\circledR}$ - Plaster of Paris blend was selected for further development based on the lower cost of the Ciment Fondu ${ }^{\circledR}$.

The second tier screening was performed to identify water to cement ratios and additives for obtaining flowable grouts to meet the P-Reactor production and placement requirements. The water to Ciment Fondu ${ }^{\circledR}$ plus Plaster of Paris ratio did not effect the set time but mixes with a higher water to cement ratio were initially more fluid. Selected results are listed in Table 4-1 and indicate that the reactor vessel grouting application requires a set retarder to achieve the required working time. Several set retarders were evaluated. Selected results are presented in Table 4-2.

Table 4-1. Summary of first and second tier screening for blended Ciment Fondu ${ }^{\circledR}$ - Plaster of Paris mixes.

\begin{tabular}{|c|c|c|c|c|c|c|c|c|}
\hline $\begin{array}{l}\text { Mix } \\
\text { No. }\end{array}$ & \multicolumn{2}{|c|}{$\begin{array}{c}\text { Proportions } \\
\text { (wt. \%) }\end{array}$} & $\begin{array}{c}\text { Water: } \\
\text { Fondu+ } \\
\text { Plaster of } \\
\text { Paris } \\
\end{array}$ & $\begin{array}{c}\text { Fresh } \\
\text { Properties }\end{array}$ & $\begin{array}{c}\text { Set } \\
\text { time }\end{array}$ & $\begin{array}{c}\text { Compressive } \\
\text { Strength } \\
\text { (psi) } \\
\end{array}$ & $\begin{array}{c}\text { Unit } \\
\text { Weight }\end{array}$ & pH \\
\hline FG-2 & $\begin{array}{l}\text { Ciment Fondu } \\
\text { Plaster of Paris } \\
\text { Class F-Fly Ash } \\
\text { Masonry Sand } \\
\text { Water }\end{array}$ & $\begin{array}{r}9.29 \\
4.65 \\
30.15 \\
30.02 \\
25.89\end{array}$ & 1.86 & $\begin{array}{l}\text { Very fluid but } \\
\text { not pourable } \\
\text { after } 5 \text { minutes } \\
\text { static } \\
\text { condition }\end{array}$ & $\begin{array}{l}<60 \\
\min .\end{array}$ & NM & NM & $9-10$ \\
\hline FG-3 & $\begin{array}{l}\text { Ciment Fondu }{ }^{(\mathbb{}} \\
\text { Plaster of Paris } \\
\text { Class F-Fly Ash } \\
\text { Masonry Sand } \\
\text { Water }\end{array}$ & $\begin{array}{r}9.24 \\
4.61 \\
30.05 \\
30.13 \\
25.97\end{array}$ & 1.87 & $\begin{array}{l}\text { Not pourable } \\
\text { after } 5 \\
\text { minutes static } \\
\text { condition }\end{array}$ & $\begin{array}{l}<60 \\
\min .\end{array}$ & $\mathrm{NM}$ & $\begin{array}{c}1.87 \\
\mathrm{~g} / \mathrm{cc} \\
115.6 \\
\mathrm{lbs} / \mathrm{cu} \mathrm{ft}\end{array}$ & $9-10$ \\
\hline FG-9-1 & $\begin{array}{l}\text { Ciment Fondu }{ }^{(\mathbb{}} \\
\text { Plaster of Paris } \\
\text { Class F-Fly Ash } \\
\text { Masonry Sand } \\
\text { Water }\end{array}$ & $\begin{array}{r}8.47 \\
4.25 \\
14.15 \\
56.46 \\
16.67\end{array}$ & 1.31 & $\begin{array}{l}\text { Initial flow } \\
6.25 \text { inches } \\
\text { Not pourable } \\
\text { after } 5 \\
\text { minutes }\end{array}$ & $\begin{array}{l}<60 \\
\min .\end{array}$ & $\begin{array}{c}1790 @ 4 \\
\text { days }\end{array}$ & NM & NM \\
\hline
\end{tabular}

$\mathrm{NM}=$ Not Measured. 


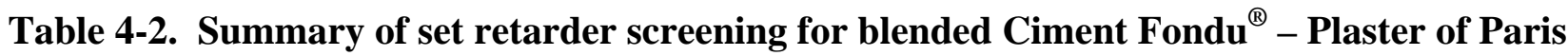
mixes.

\begin{tabular}{|c|c|c|c|c|c|c|c|c|}
\hline $\begin{array}{l}\text { Mix } \\
\text { No. }\end{array}$ & \multicolumn{2}{|c|}{$\begin{array}{c}\text { Proportions } \\
\text { (wt. \%) }\end{array}$} & $\begin{array}{l}\text { Water: } \\
\text { Fondu+ } \\
\text { Plaster } \\
\text { of Paris }\end{array}$ & $\begin{array}{c}\text { Fresh } \\
\text { Properties }\end{array}$ & $\begin{array}{c}\text { Set } \\
\text { time }\end{array}$ & $\begin{array}{c}\text { Compressive } \\
\text { Strength } \\
\text { (psi) }\end{array}$ & $\begin{array}{c}\text { Unit } \\
\text { Weight }\end{array}$ & pH \\
\hline FG-9-2 & $\begin{array}{l}\text { Ciment Fondu } \\
\text { Plaster of Paris } \\
\text { Class F-Fly Ash } \\
\text { Masonry Sand } \\
\text { Water } \\
\text { Boric Acid }\end{array}$ & $\begin{array}{c}8.46 \\
4.24 \\
14.13 \\
56.38 \\
16.64 \\
0.15 \\
\end{array}$ & 1.31 & $\begin{array}{l}\text { Fluid but not } \\
\text { pourable after } 5 \\
\text { minutes static } \\
\text { condition } \\
\text { Segregation / } \\
\text { Bleed }\end{array}$ & NM & NM & NM & NM \\
\hline FG-9-4 & $\begin{array}{l}\text { Ciment Fondu }^{\circledR} \\
\text { Plaster of Paris } \\
\text { Class F-Fly Ash } \\
\text { Masonry Sand } \\
\text { Water } \\
\text { Recover }^{\circledR}\end{array}$ & $\begin{array}{c}8.47 \\
4.25 \\
14.14 \\
56.43 \\
16.66 \\
0.05 \\
\end{array}$ & 1.31 & $\begin{array}{l}\text { Initially fluid } \\
\text { Not pourable } \\
\text { after } 5 \text { minutes } \\
\text { static condition } \\
\text { Segregation }\end{array}$ & NM & NM & NM & NM \\
\hline FG-9-7 & $\begin{array}{l}\text { Ciment Fondu }^{\circledR} \\
\text { Plaster of Paris } \\
\text { Class F-Fly Ash } \\
\text { Masonry Sand } \\
\text { Water } \\
\text { Borax }\end{array}$ & $\begin{array}{c}8.47 \\
4.25 \\
14.13 \\
56.38 \\
16.64 \\
0.15\end{array}$ & 1.31 & $\begin{array}{l}\text { Fluid and } \\
\text { pourable after } 5 \\
\text { minutes but not } \\
\text { after } 10 \text { minutes } \\
\text { static condition } \\
\text { Segregation / } \\
\text { High Bleed }\end{array}$ & NM & NM & NM & NM \\
\hline $\begin{array}{l}\text { FG-9- } \\
26 \mathrm{~d}\end{array}$ & $\begin{array}{l}\text { Ciment Fondu }^{\circledR} \\
\text { Plaster of Paris } \\
\text { Class F-Fly Ash } \\
\text { Masonry Sand } \\
\text { Water } \\
\text { SIKA VC }{ }^{\circledR} 2100 \\
\text { KIM } 301 \\
\text { Daratard }^{\circledR} \mathbf{1 7}\end{array}$ & $\begin{array}{l}8.75 \\
4.36 \\
14.81 \\
49.81 \\
21.84 \\
0.18 \\
0.13 \\
0.13 \\
\end{array}$ & 1.67 & $\begin{array}{l}\text { Initial flow = } 8 \\
\text { inches } \\
\text { No flow @ } 15 \\
\text { minutes } \\
\text { Segregation }\end{array}$ & NM & NM & NM & $\begin{array}{c}9.0 \\
\text { after } \\
\text { mixing } \\
\text { for } 30 \\
\text { minutes }\end{array}$ \\
\hline $\begin{array}{l}\text { FG-9- } \\
26 \mathrm{e}\end{array}$ & $\begin{array}{l}\text { Ciment Fondu }^{\circledR} \\
\text { Plaster of Paris } \\
\text { Class F-Fly Ash } \\
\text { Masonry Sand } \\
\text { Water } \\
\text { KIM }^{\circledR} 301 \\
\text { SIKA VC }{ }^{\circledR} 2100 \\
\text { Citric Acid }\end{array}$ & $\begin{array}{c}9.04 \\
4.52 \\
15.33 \\
51.59 \\
19.19 \\
0.14 \\
0.08 \\
0.11\end{array}$ & 1.42 & $\begin{array}{l}\text { Initial flow =9 } \\
\text { inches } \\
8.63 \text { inches at } \\
15 \mathrm{~min} \\
7.63 @ 30 \mathrm{~min} \\
8.5 @ 45 \mathrm{~min} \\
\text { Segregation / } \\
\text { Bleed }\end{array}$ & $\begin{array}{l}>15 \text { to } \\
<24 \mathrm{hr}\end{array}$ & $314 @ 1$ day & $\begin{array}{c}124.6 \\
\mathrm{lbs} / \mathrm{cu} \mathrm{ft}\end{array}$ & NM \\
\hline
\end{tabular}

$\mathrm{NM}=$ Not Measured.

Boric acid, borax, and citric acid were the most effective set retarders. Boric acid and citric acid were used in subsequent testing. Next, high range water reducers and mid range water reducers were also tested in an attempt to reduce the water to cement ratio to control segregation and bleed and also to achieve higher strengths and faster strength gain. Selected results are presented in Table 4-3. The polycarboxylate-type high range water reducers, SIKA ViscoCrete ${ }^{\circledR} 2100$ and ADVA $^{\circledR} 408$ performed the best. However bleed and segregation were still observed. Therefore, viscosity modifying admixtures (VMA) were evaluated. SIKA ViscoCrete ${ }^{\circledR} 2100$ was selected for further testing with VMAs. 
Table 4-3. Summary of water reducing and high range water reducing admixture screening for blended Ciment Fondu ${ }^{\circledR}$ - Plaster of Paris mixes.

\begin{tabular}{|c|c|c|c|c|c|c|c|}
\hline Mix No. & $\begin{array}{l}\text { Proportions } \\
\text { (wt. \%) }\end{array}$ & $\begin{array}{l}\text { Water: } \\
\text { Fondu }^{\circledR}+ \\
\text { Plaster of } \\
\text { Paris }\end{array}$ & $\begin{array}{c}\text { Fresh } \\
\text { Properties }\end{array}$ & $\begin{array}{c}\text { Set } \\
\text { time }\end{array}$ & $\begin{array}{c}\text { Compressive } \\
\text { Strength } \\
\text { (psi) }\end{array}$ & $\begin{array}{c}\text { Unit } \\
\text { Weight }\end{array}$ & pH \\
\hline FG-9-5 & $\begin{array}{lr}\text { Ciment Fondu }^{\circledR 8} & 8.47 \\
\text { Plaster of Paris } & 4.25 \\
\text { Class F-Fly Ash } & 14.15 \\
\text { Masonry Sand } & 56.46 \\
\text { Water }^{\text {Superplast }}{ }^{\circledR} & 16.67 \\
\text { 1000 } & 0.004\end{array}$ & 1.31 & $\begin{array}{l}\text { Fluid but not } \\
\text { pourable after } 5 \\
\text { minutes static } \\
\text { condition. } \\
\text { Much } \\
\text { Segregation / } \\
\text { Bleed }\end{array}$ & NM & NM & NM & NM \\
\hline FG-9-6 & $\begin{array}{lr}\text { Ciment Fondu }^{\circledR} & 7.54 \\
\text { Plaster of Paris } & 3.78 \\
\text { Class F-Fly Ash } & 12.58 \\
\text { Masonry Sand } & 50.21 \\
\text { Water } & 25.88 \\
\text { WRDA }^{\circledR} \text { 35 } & 0.01 \\
\end{array}$ & 2.29 & $\begin{array}{l}\text { Initially fluid } \\
\text { but not pourable } \\
\text { after } 5 \text { minutes } \\
\text { static condition } \\
\text { Segregation / } \\
\text { Bleed }\end{array}$ & NM & NM & NM & NM \\
\hline FG-9-10 & $\begin{array}{lr}\text { Ciment Fondu }^{\circledR} & 8.47 \\
\text { Plaster of Paris } & 4.25 \\
\text { Class F-Fly Ash } & 14.14 \\
\text { Masonry Sand } & 56.45 \\
\text { Water } & 16.66 \\
\text { ADVA }^{\circledR} \text { 408 } & 0.03 \\
\end{array}$ & 1.31 & $\begin{array}{l}\text { Initially fluid } \\
\text { not pourable } \\
\text { after } 5 \text { minutes } \\
\text { static condition }\end{array}$ & NM & NM & NM & NM \\
\hline $\begin{array}{l}\text { FG-9-8 } \\
\text { FG-9-14 } \\
\end{array}$ & $\begin{array}{lr}\text { Ciment Fondu }^{\circledR} & 8.47 \\
\text { Plaster of Paris } & 4.25 \\
\text { Class F-Fly Ash } & 14.15 \\
\text { Masonry Sand } & 56.44 \\
\text { Water } & 16.67 \\
\text { SIKA VC }^{\circledR} \text { 2100 } & 0.02\end{array}$ & 1.31 & $\begin{array}{l}\text { Fluid and } \\
\text { pourable after } 5 \\
\text { minutes } \\
\text { Segregation / } \\
\text { No Bleed } \\
\text { No flow at } 15 \\
\text { minutes }\end{array}$ & NM & NM & NM & NM \\
\hline FG-9-16 & $\begin{array}{lr}\text { Ciment Fondu }^{\circledR} & 8.47 \\
\text { Plaster of Paris } & 4.25 \\
\text { Class F-Fly Ash } & 14.14 \\
\text { Masonry Sand } & 56.43 \\
\text { Water } & 16.66 \\
\text { SIKA VC }^{\circledR} \text { 2100 } & 0.05 \\
& \\
\text { (3x more SIKA VC } & \text { 2100 than } \\
\text { Mix 9-8) }\end{array}$ & 1.31 & $\begin{array}{l}\text { Fluid and } \\
\text { pourable after } 5 \\
\text { minutes } \\
\text { No flow at } 15 \\
\text { minutes } \\
\text { Segregation } \\
\text { Some bleed }\end{array}$ & NM & NM & NM & NM \\
\hline FG-9-13 & 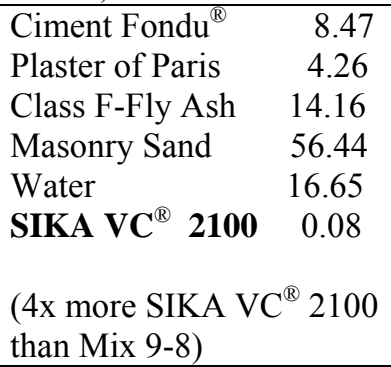 & 1.31 & $\begin{array}{l}\text { Initial Flow = } \\
9.0 \text { inches @ } \\
15 \text { min. } \\
\text { Static flow = } \\
3.5 \text { inches@ } \\
15 \text { min. } \\
\text { No flow@30 } \\
\text { min. } \\
\text { High Bleed }\end{array}$ & $\begin{array}{l}<1 \\
\mathrm{hr}\end{array}$ & $\begin{array}{c}1230 \text { psi } @ \\
1 \text { day }\end{array}$ & NM & NM \\
\hline
\end{tabular}

$\mathrm{NM}=$ Not Measured.

The combination of SIKA ViscoCrete ${ }^{\circledR} 2100$ and Diutan gum was evaluated next because zero bleed mixes with acceptable rheology (initial flows) were obtained with these materials in the flowable structural fills used for the majority of the below grade reactor facility ISD. Selected 
results are presented in Table 4-4. Zero bleed blended calcium aluminate - calcium sulfate grouts with high initial flows could be produced with a combination of SIKA ViscoCrete ${ }^{\circledR} 2100$ and Diutan gum. However, the short set times of $<1$ hour indicate that additional set retardation is required to achieve the dynamic and static working times required for reactor vessel filling. Consequently, three types of admixtures, a set retarder (boric acid or citric acid), VMA, and HRWR are needed to meet the requirements for reactor vessel grout.

Table 4-4. Summary of high range water reducing and viscosity modifying admixtures for blended Ciment Fondu ${ }^{\circledR}$ - Plaster of Paris mixes.

\begin{tabular}{|c|c|c|c|c|c|c|c|c|}
\hline Mix No. & \multicolumn{2}{|c|}{$\begin{array}{c}\text { Proportions } \\
\text { (wt. \%) }\end{array}$} & $\begin{array}{c}\text { Water: } \\
\text { Fondu+ } \\
\text { Plaster of } \\
\text { Paris } \\
\end{array}$ & $\begin{array}{c}\text { Fresh } \\
\text { Properties }\end{array}$ & $\begin{array}{c}\text { Set } \\
\text { time }\end{array}$ & $\begin{array}{c}\text { Compressive } \\
\text { Strength } \\
\text { (psi) }\end{array}$ & $\begin{array}{c}\text { Unit } \\
\text { Weight }\end{array}$ & pH \\
\hline FG-9-22 & $\begin{array}{l}\text { Ciment Fondu }^{\circledR} \\
\text { Plaster of Paris } \\
\text { Class F-Fly Ash } \\
\text { Masonry Sand } \\
\text { Water } \\
\text { SIKA VC }{ }^{\circledR} \mathbf{2 1 0 0} \\
\text { Diutan Gum }\end{array}$ & $\begin{array}{r}8.47 \\
4.24 \\
14.14 \\
56.42 \\
16.65 \\
\mathbf{0 . 0 6} \\
\mathbf{0 . 0 2}\end{array}$ & 1.31 & $\begin{array}{l}\text { Static flow = } \\
6 \text { in. @15 min. } \\
\text { No flow @30 } \\
\text { min. } \\
\text { No bleed } \\
\text { No settlement }\end{array}$ & $\sim 1 \mathrm{hr}$ & NM & NM & NM \\
\hline FG-9-23 & $\begin{array}{l}\text { Ciment Fondu }{ }^{\circledR} \\
\text { Plaster of Paris } \\
\text { Class F-Fly Ash } \\
\text { Masonry Sand } \\
\text { Water } \\
\text { SIKA VC }{ }^{\circledR} \mathbf{2 1 0 0} \\
\text { Diutan Gum }\end{array}$ & $\begin{array}{r}8.32 \\
4.17 \\
13.90 \\
55.47 \\
18.06 \\
\mathbf{0 . 0 6} \\
\mathbf{0 . 0 2} \\
\end{array}$ & 1.44 & $\begin{array}{l}\text { Static flow = } \\
6.25 \mathrm{in} . \\
\text { @ } 15 \mathrm{~min} . \\
\text { No bleed } \\
\text { No settlement }\end{array}$ & $\sim 1 \mathrm{hr}$ & NM & NM & $\mathrm{NM}$ \\
\hline FG-9-24 & $\begin{array}{l}\text { Ciment Fondu }^{\circledR} \\
\text { Plaster of Paris } \\
\text { Class F-Fly Ash } \\
\text { Masonry Sand } \\
\text { Water } \\
\text { SIKA VC }{ }^{\circledR} \mathbf{2 1 0 0} \\
\text { Diutan Gum }\end{array}$ & $\begin{array}{r}8.47 \\
4.24 \\
14.13 \\
56.41 \\
16.65 \\
\mathbf{0 . 0 8} \\
\mathbf{0 . 0 2} \\
\end{array}$ & 1.31 & $\begin{array}{l}\text { Static flow = } \\
6.63 \mathrm{in} . \\
\text { (a) } 15 \mathrm{~min} . \\
\text { No bleed } \\
\text { No settlement }\end{array}$ & $\sim 1 \mathrm{hr}$ & NM & NM & NM \\
\hline FG-9-25 & $\begin{array}{l}\text { Ciment Fondu }^{\circledR} \\
\text { Plaster of Paris } \\
\text { Class F-Fly Ash } \\
\text { Masonry Sand } \\
\text { Water } \\
\text { SIKA VC }{ }^{\circledR} \mathbf{2 1 0 0} \\
\text { Diutan Gum }\end{array}$ & $\begin{array}{r}8.32 \\
4.17 \\
13.90 \\
55.46 \\
18.05 \\
\mathbf{0 . 0 8} \\
\mathbf{0 . 0 2}\end{array}$ & 1.44 & $\begin{array}{l}\text { Static flow = } \\
6.75 \text { in. } \\
\text { @ } 15 \text { min. } \\
\text { Pourable @ } \\
30 \text { min. } \\
\text { Not pourable } \\
\text { @ } 40 \text { min. } \\
\text { No bleed } \\
\text { No settlement }\end{array}$ & $\sim 1 \mathrm{hr}$ & $\mathrm{NM}$ & NM & NM \\
\hline
\end{tabular}

$\mathrm{NM}=$ Not Measured

Alternative VMAs were also tested because of the unique cement-based system and unique application. Selected results are presented in Table 4-5. Cembinder ${ }^{\circledR} 50$, a colloidal silica, and bentonite clay were not as effective as the Diutan Gum. 
Table 4-5. Summary of alternative viscosity modifying admixtures for blended Ciment Fondu ${ }^{\circledR}$ - Plaster of Paris mixes.

\begin{tabular}{|c|c|c|c|c|c|c|c|c|}
\hline Mix No. & \multicolumn{2}{|c|}{$\begin{array}{c}\text { Proportions } \\
\text { (wt. \%) }\end{array}$} & $\begin{array}{l}\text { Water: } \\
\text { Fondu + } \\
\text { Plaster of } \\
\text { Paris } \\
\end{array}$ & $\begin{array}{c}\text { Fresh } \\
\text { Properties }\end{array}$ & $\begin{array}{l}\text { Set } \\
\text { time }\end{array}$ & $\begin{array}{c}\text { Compressive } \\
\text { Strength } \\
\text { (psi) }\end{array}$ & $\begin{array}{c}\text { Unit } \\
\text { Weight }\end{array}$ & pH \\
\hline FG-9-30 & $\begin{array}{l}\text { Ciment Fondu }{ }^{\circledR} \\
\text { Plaster of Paris } \\
\text { Class F-Fly Ash } \\
\text { Masonry Sand } \\
\text { Water } \\
\text { SIKA VC }^{\circledR} \mathbf{2 1 0 0} \\
\text { Cembinder }^{\circledR} \mathbf{5 0}\end{array}$ & \begin{tabular}{r|}
8.30 \\
4.16 \\
13.86 \\
55.32 \\
18.01 \\
$\mathbf{0 . 0 8}$ \\
$\mathbf{0 . 2 7}$
\end{tabular} & 1.44 & $\begin{array}{l}\text { Static flow @ } \\
15 \text { min. } 5.63 \text { in } \\
\text { No flow @ } 30 \\
\text { min. } \\
\text { High Bleed } \\
\text { and High } \\
\text { Settlement }\end{array}$ & NM & NM & NM & NM \\
\hline FG-9-42 & $\begin{array}{l}\text { Ciment Fondu }^{\circledR} \\
\text { Plaster of Paris } \\
\text { Class F-Fly Ash } \\
\text { Masonry Sand } \\
\text { Water } \\
\text { SIKA VC }{ }^{\circledR} \mathbf{2 1 0 0} \\
\text { Bentonite }\end{array}$ & $\begin{array}{r}8.30 \\
4.16 \\
13.86 \\
55.32 \\
18.00 \\
\mathbf{0 . 0 8} \\
\mathbf{0 . 2 8}\end{array}$ & 1.44 & $\begin{array}{l}\text { Static flow @ } \\
15 \text { min.0 in } \\
\text { No bleed } \\
\text { No settlement }\end{array}$ & NM & NM & NM & NM \\
\hline
\end{tabular}

$\mathrm{NM}=$ Not Measured.

\subsection{Laboratory Bench Scale-up and Test Results}

Bench-scale up testing at SRS was performed to identify a grout mix design for full scale-up testing at Gibson's Pressure Grouting Services Inc., Smyrna, GA. Based on the results of the screening mixes, processing admixtures and the proportion of binder to inert fly ash and sand were selected for scale-up to a batch size of 0.5 cubic foot.

\subsubsection{Citric Acid}

Citric acid was used in the first set of bench scale-up tests because for an equivalent amount it provided longer set retardation compared to boric acid. $\mathrm{KIM}^{\circledR} 301$ was also added to all of the mixes in bench scale-up tests. ${ }^{13}$ Results are listed in Table 4-6. The amount of citric acid in Mix FG9-26E was twice the amount in FG9-26G. Both mixes met the requirements for reactor fill grout. Mix FG9-26G was selected for the bench scale-up testing.

The bench scale-up test consisted of making a 0.5 cubic foot batch and pouring the resulting grout into a pan that contained physical obstructions to impede flow. See Figure 4-1. The grout mixing procedure was as follows:

- Pre-blend the solid cementitious reagents including the $\mathrm{KIM}^{\circledR} 301$

- Add solid boric acid set retarder to the mixing water in a one cubic foot Hobart mixer.

- Add the sand and then the fly ash

- Add the pre blended cementitious ingredients

- Add the liquid HRWR to the slurry during the first minute of mixing

- Mix for 10 minutes

- Pour the resulting grout into the test pan through a ASTM C-939 flow cone (1/2 inch funnel opening) and measure the time for the flow cone to empty. (The ASTM C-939

${ }^{13} \mathrm{KIM}^{\circledR} 301$ was included in the reactor fill grout mix at the request of SRNS SDD Engineering. 
procedure requires that the flow cone be cleaned between measurements. However, this was not done so the increased times are probably less than measured.)

- Continue filling pan using flow cone and measure the time to empty for each addition. Record time of each placement. (The flow cone was not rinsed between placements.)

Table 4-6. Summary of bench scale-up testing with citric acid.

\begin{tabular}{|c|c|c|c|c|c|c|c|c|}
\hline Mix No. & \multicolumn{2}{|c|}{$\begin{array}{c}\text { Proportions } \\
\text { (wt. \%) }\end{array}$} & $\begin{array}{c}\text { Water: } \\
\text { Fondu + } \\
\text { Plaster of } \\
\text { Paris }\end{array}$ & $\begin{array}{c}\text { Fresh } \\
\text { Properties }\end{array}$ & $\begin{array}{c}\text { Set } \\
\text { time }\end{array}$ & $\begin{array}{l}\text { Compressive } \\
\text { Strength } \\
\text { (psi) }\end{array}$ & $\begin{array}{c}\text { Unit } \\
\text { Weight }\end{array}$ & pH \\
\hline FG-9-26E & $\begin{array}{l}\text { Ciment Fondu }^{\circledR} \\
\text { Plaster of Paris } \\
\text { Class F-Fly Ash } \\
\text { Masonry Sand } \\
\text { Water } \\
\text { KIM }^{\circledR} 301 \\
\text { Diutan Gum } \\
\text { SIKA VC }{ }^{\circledR} 2100 \\
\text { Citric Acid }\end{array}$ & $\begin{array}{c}9.03 \\
4.52 \\
15.33 \\
51.59 \\
19.19 \\
0.14 \\
0.01 \\
0.08 \\
0.11\end{array}$ & 1.42 & $\begin{array}{l}\text { Static flow } \\
9.0 \text { in @ initial } \\
8.13 @ 15 \mathrm{~min} \\
7.63 @ 30 \mathrm{~min} \\
8.5 @ 45 \mathrm{~min} \\
\text { No bleed } \\
\text { No settlement }\end{array}$ & NM & NM & NM & $9-10$ \\
\hline FG9-26E1 & $\begin{array}{l}\text { Ciment Fondu }^{\circledR} \\
\text { Plaster of Paris } \\
\text { Class F-Fly Ash } \\
\text { Masonry Sand } \\
\text { Water } \\
\text { KIM }^{\circledR} 301 \\
\text { Diutan Gum } \\
\text { SIKA VC } 2100 \\
\text { Citric Acid }\end{array}$ & $\begin{array}{r}9.05 \\
4.52 \\
15.32 \\
51.58 \\
19.19 \\
0.13 \\
0.01 \\
0.08 \\
0.11 \\
\end{array}$ & 1.42 & $\begin{array}{l}\text { Static flow } \\
9.0 \text { in @ initial } \\
8.63 @ 15 \mathrm{~min} \\
7.63 @ 30 \mathrm{~min} \\
8.5 @ 45 \mathrm{~min} \\
\text { No bleed } \\
\text { No settlement }\end{array}$ & $\begin{array}{l}\sim 20 \\
\mathrm{hr}\end{array}$ & $\begin{array}{c}314 @ 24 \text { hr } \\
753 @ 202 \text { days }\end{array}$ & $\begin{array}{c}124.6 \\
\mathrm{lb} / \mathrm{cu} \mathrm{ft}\end{array}$ & NM \\
\hline FG9-26G & $\begin{array}{l}\left.\text { Ciment Fondu }^{(}\right) \\
\text {Plaster of Paris } \\
\text { Class F-Fly Ash } \\
\text { Masonry Sand } \\
\text { Water } \\
\text { KIM }^{\circledR} 301 \\
\text { Diutan Gum } \\
\text { SIKA VC } 2100 \\
\text { Citric Acid }\end{array}$ & $\begin{array}{r}9.06 \\
4.54 \\
15.32 \\
51.60 \\
19.19 \\
0.14 \\
0.02 \\
0.10 \\
0.05\end{array}$ & 1.41 & $\begin{array}{l}\text { Initial flow }= \\
8.5 \text { inch } \\
6.75 \text { inches } \\
@ 30 \text { min. }\end{array}$ & $\begin{array}{c}<22 \\
\mathrm{hr}\end{array}$ & $\begin{array}{c}726 @ 36 \text { hr } \\
1040 @ 202 \text { days }\end{array}$ & NM & NM \\
\hline $\begin{array}{l}\text { FG9- } \\
26 \text { G2 }\end{array}$ & $\begin{array}{l}\text { Ciment Fondu }{ }^{\circledR} \\
\text { Plaster of Paris } \\
\text { Class F-Fly Ash } \\
\text { Masonry Sand } \\
\text { Water } \\
\text { KIM }^{\circledR} 301 \\
\text { Diutan Gum } \\
\text { SIKA VC VC } 2100 \\
\text { Citric Acid }\end{array}$ & $\begin{array}{c}9.05 \\
4.53 \\
15.32 \\
51.60 \\
19.20 \\
0.14 \\
0.02 \\
0.09 \\
0.06\end{array}$ & 1.41 & $\begin{array}{l}\text { Dynamic } \\
\text { Flow Cone } \\
\text { (after minutes } \\
\text { of mixing) } \\
29 \mathrm{~s} \text { after } 10 \mathrm{~min} \text {. } \\
30 \mathrm{~s} \text { after } 10 \mathrm{~min} \text {. } \\
29 \mathrm{~s} \text { after } 16 \mathrm{~min} \text {. } \\
31 \mathrm{~s} \text { after } 18 \mathrm{~min} \text {. } \\
32 \mathrm{~s} \text { after } 20 \mathrm{~min} \text {. } \\
32 \mathrm{~s} \text { after } 22 \mathrm{~min} \text {. } \\
35 \mathrm{~s} \text { after } 24 \mathrm{~min} \text {. } \\
\text { No bleed }\end{array}$ & $\begin{array}{c}<22 \\
\mathrm{hr}\end{array}$ & $\begin{array}{c}763 @ 5 \text { days } \\
1079 @ 201 \text { days }\end{array}$ & NM & NM \\
\hline
\end{tabular}

$\mathrm{NM}=$ Not measured 


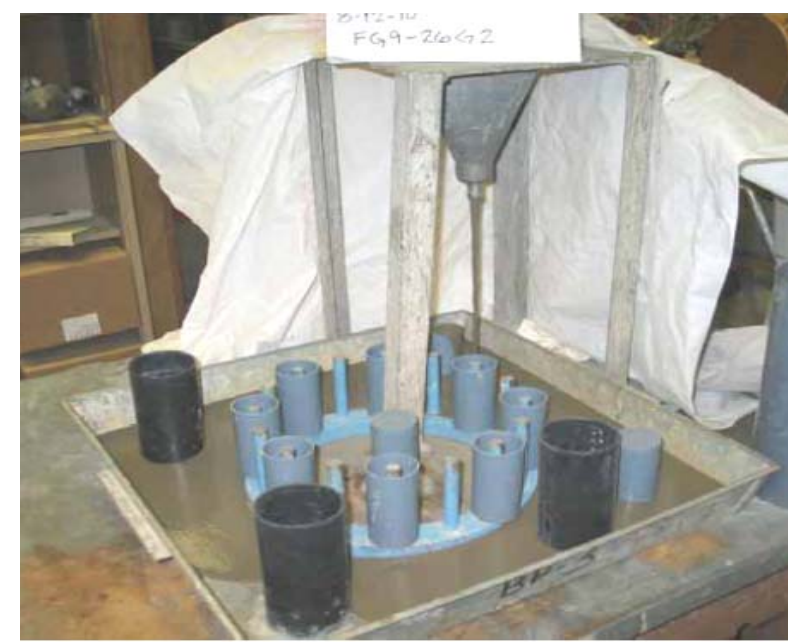

(a)

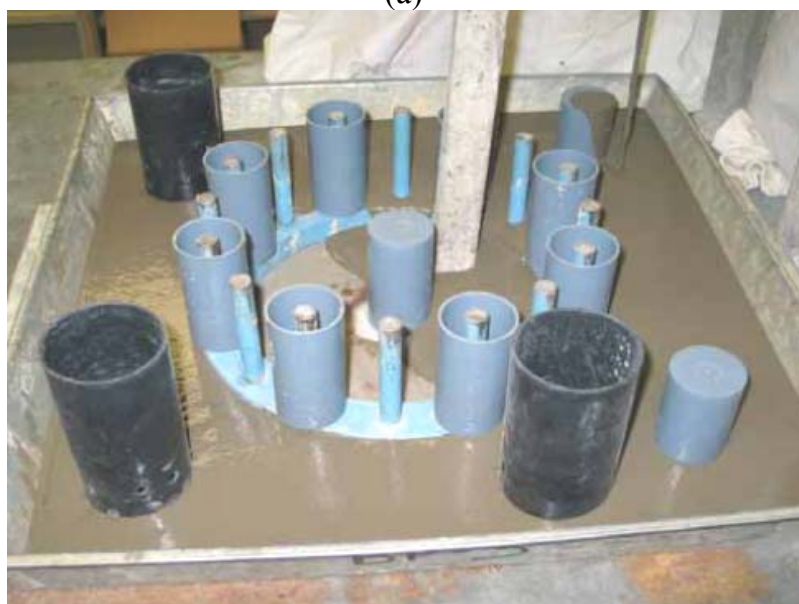

(b)

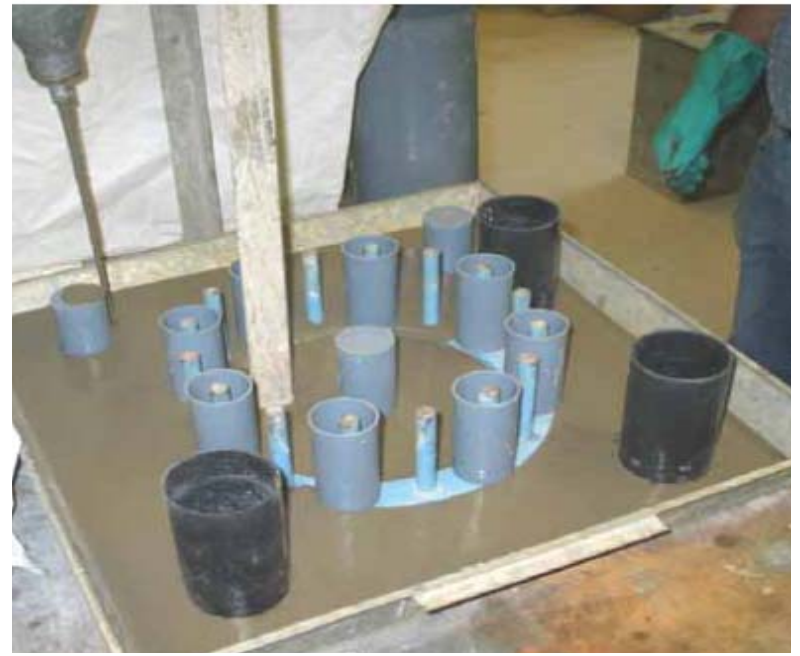

(c)

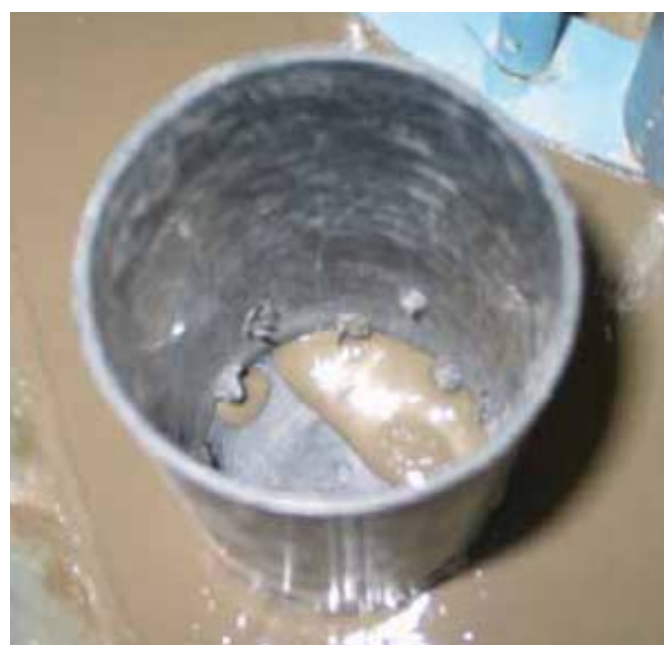

(d)

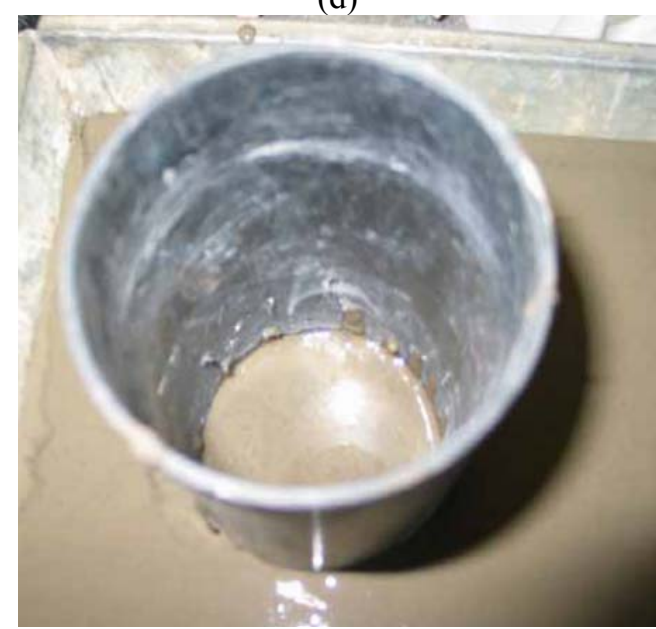

(e)

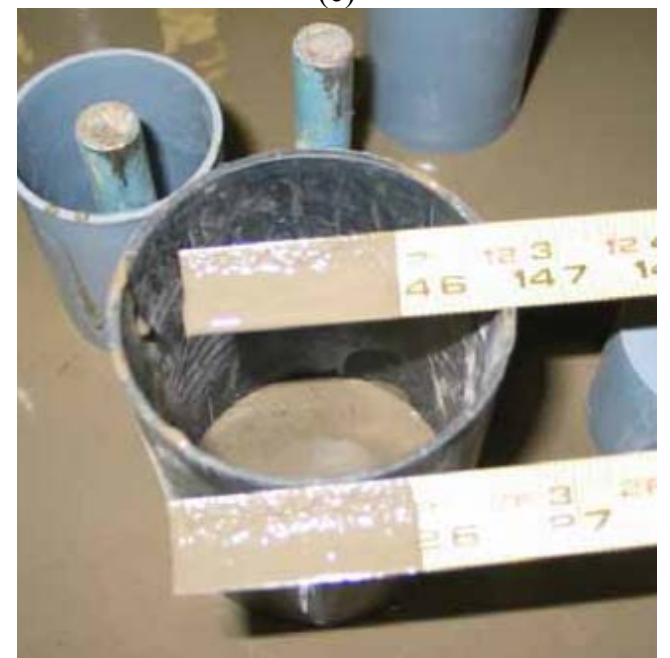

(f)

Figure 4-1. Bench scale-up flow test for citric acid formulation. Progressive filling of container with obstructions (a to c). Progressive filling of obstructions with 3/16 inch diameter holes (d to e) and 3/8 inch wide slit (f). 


\subsubsection{Boric Acid}

The bench scale-up testing was repeated as described in Section 4.2.1 with boric acid as the set retarder. ${ }^{14}$ Fresh and cured property results indicated that boric acid also resulted in mixes that met the requirements for P-Reactor vessel grout fill. The flow cone was filled eight times over a twelve minute period. Flows were measured for each batch. The time to empty the cone increased for each successive batch. (The ASTM C-939 procedure requires that the flow cone be cleaned between measurements. However, this was not done so the increased times are probably less than measured.) Results are presented in Table 4-7 and Figures 4-2 and 4-3.

\section{Table 4-7. Summary of bench scale-up testing with boric acid.}

\begin{tabular}{|c|c|c|c|c|c|c|c|c|}
\hline Mix No. & $\begin{array}{l}\text { Proportions } \\
\text { (wt. \%) }\end{array}$ & & $\begin{array}{l}\text { Water: } \\
\text { Fondu + } \\
\text { Plaster } \\
\text { of Paris }\end{array}$ & $\begin{array}{c}\text { Fresh } \\
\text { Properties }\end{array}$ & $\begin{array}{l}\text { Set } \\
\text { time }\end{array}$ & $\begin{array}{l}\text { Compressive } \\
\text { Strength } \\
\text { (psi) }\end{array}$ & $\begin{array}{c}\text { Unit } \\
\text { Weight }\end{array}$ & pH \\
\hline FG-9-26F & $\begin{array}{l}\text { Ciment Fondu }^{\circledR} \\
\text { Plaster of Paris } \\
\text { Class F-Fly Ash } \\
\text { Masonry Sand } \\
\text { Water } \\
\text { KIM }^{\circledR} 301 \\
\text { Diutan Gum } \\
\text { SIKA VC } \\
\text { Boric Acid } \\
\end{array}$ & $\begin{array}{r}9.03 \\
4.53 \\
15.27 \\
51.41 \\
19.12 \\
0.14 \\
0.02 \\
0.09 \\
0.39 \\
\end{array}$ & 1.41 & $\begin{array}{l}\text { Static flow } \\
9.25 \text { inch } @ \\
\text { initial } \\
8.5 @ 15 \mathrm{~min} \\
7.25 @ 30 \mathrm{~min} \\
8.0 @ 45 \mathrm{~min} \\
\text { Bleed after } 24 \mathrm{hr}\end{array}$ & $\begin{array}{l}>6 \\
\text { days }\end{array}$ & NM & 124.5 & NM \\
\hline FG-9-26I & $\begin{array}{l}\text { Ciment Fondu }^{\circledR} \\
\text { Plaster of Paris } \\
\text { Class F-Fly Ash } \\
\text { Masonry Sand } \\
\text { Water } \\
\text { KIM }^{\circledR} 301 \\
\text { Diutan Gum } \\
\text { SIKA VC }{ }^{\circledR} 2100 \\
\text { Boric Acid }\end{array}$ & $\begin{array}{c}9.06 \\
4.52 \\
15.30 \\
51.53 \\
19.16 \\
0.14 \\
0.02 \\
0.09 \\
0.19 \\
\end{array}$ & 1.41 & $\begin{array}{l}\text { Static flow } \\
8.5 \text { in. @ initial } \\
7.25 @ 30 \mathrm{~min} \\
6.5 @ 45 \mathrm{~min} \\
\text { No bleed } \\
\text { No settlement }\end{array}$ & $\begin{array}{c}<24 \\
\mathrm{hr}\end{array}$ & $\begin{array}{c}564 @ 36 \text { hr } \\
600 @ 5 \text { days } \\
970 @ 202 \\
\text { days }\end{array}$ & 124.5 & NM \\
\hline $\begin{array}{l}\text { FG-9- } \\
26 I 2\end{array}$ & $\begin{array}{l}\text { Ciment Fondu }^{\circledR} \\
\text { Plaster of Paris } \\
\text { Class F-Fly Ash } \\
\text { Masonry Sand } \\
\text { Water } \\
\text { KIM }^{\circledR} 301 \\
\text { Diutan Gum }_{\text {SIKA VC }}{ }^{\circledR} 2100 \\
\text { Boric Acid }\end{array}$ & $\begin{array}{r}9.04 \\
4.53 \\
15.30 \\
51.53 \\
19.17 \\
0.14 \\
0.02 \\
0.09 \\
0.19\end{array}$ & 1.41 & $\begin{array}{l}\text { Static flow } \\
7.38 \text { in. @ initial } \\
6.25 \text { in } @ 15 \\
5.75 @ 30 \text { min } \\
4.5 @ 45 \text { min } \\
\text { No bleed } \\
\text { Dynamic/ } \\
\text { Flow Cone } \\
\text { (after minutes } \\
\text { of mixing) } \\
32 \text { after } 8 \text { min. } \\
33 \mathrm{~s} \text { after } 10 \\
32 \mathrm{~s} \text { after } 11 \\
33 \mathrm{~s} \text { after } 12 \\
34 \mathrm{~s} \text { after } 14 \\
35 \mathrm{~s} \text { after } 16 \\
38 \mathrm{~s} \text { after } 17 \\
39 \mathrm{~s} \text { after } 20\end{array}$ & $\begin{array}{c}<24 \\
\mathrm{hr}\end{array}$ & $\begin{array}{c}598 @ 5 \text { days } \\
1200 @ 201 \\
\text { days }\end{array}$ & 124.9 & NM \\
\hline
\end{tabular}

\footnotetext{
${ }^{14}$ Two candidate mixes were identified for full scale-up testing. Another reason for testing boric acid is that it was the set retarder recommended for the other grout, a magnesium phosphate-based material recommended for the full scale-up evaluation. Two mixes were considered because this was the first flowable fill application of these uniquely modified materials.
} 


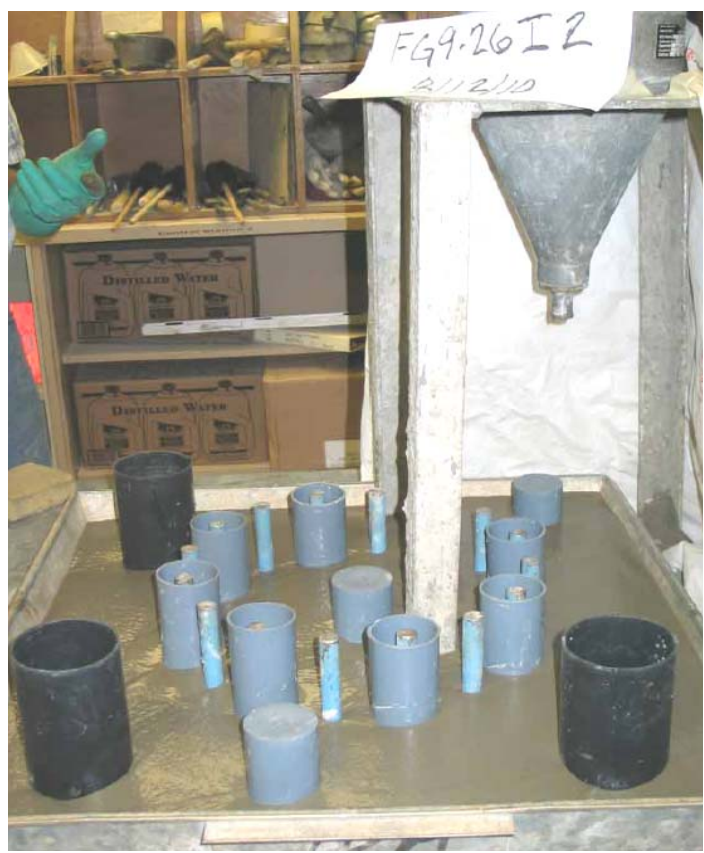

(a)

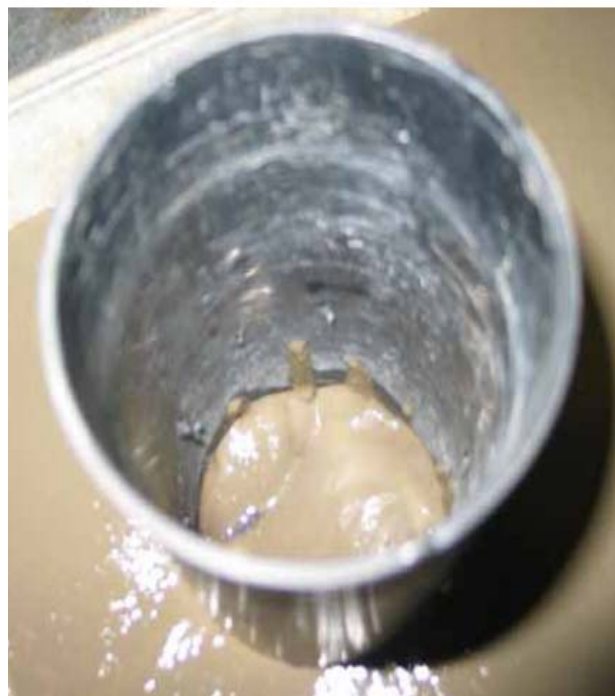

(b)

Figure 4-2. Bench scale-up flow test for boric acid formulation. Flowable grout placed in a container with obstructions (a). Grout flowing into obstructions via 3/16 inch diameter holes (b).

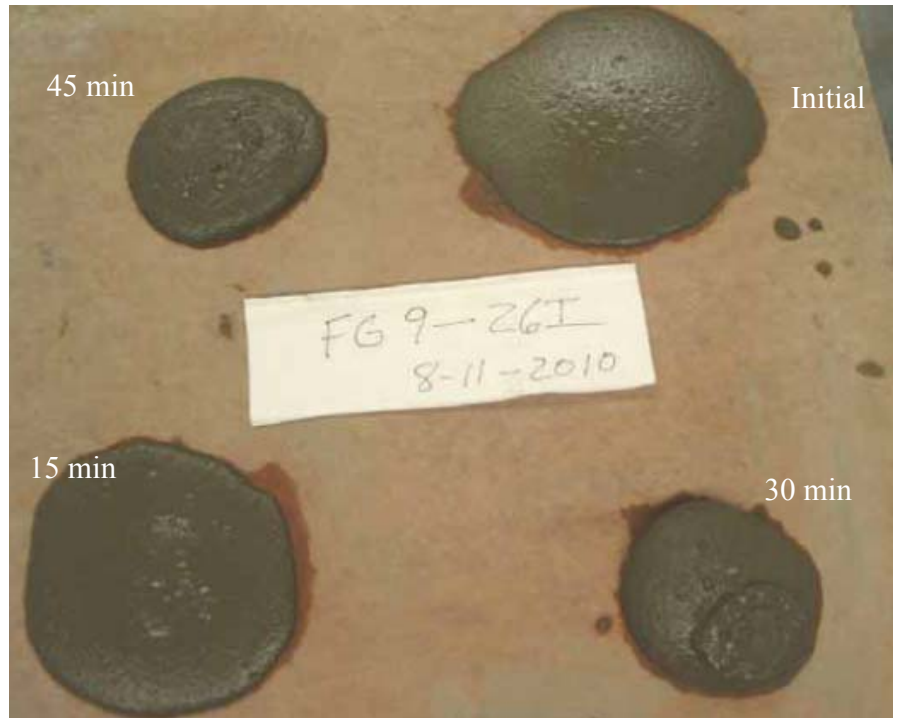

Figure 4-3. Static flow test results for Mix FG-26I (boric acid mix) per modified ASTM D6103. Initial spread and spread after increasing times under static conditions. 


\subsection{Summary of Bench-Scale Testing}

Both citric acid and boric acid were effective set retarders in laboratory bench scale-up testing of the calcium aluminate - calcium sulfate cement grouts. For an equivalent dose by weight, citric acid was more effective than the boric acid. However, boric acid was selected for the scale-up pumping and mock up vessel testing because it was inorganic. Also boric acid was found to be the most effective set retarder for the magnesium potassium phosphate grout and a supply for mock up testing had already been purchased.

The mixes retarded with citric acid and boric acid flowed around the obstructions and through 1.0 inch gaps between obstructions. Both grouts also flowed into the obstructions through $3 / 16$ inch holes and 3/8 inch wide slits. See Figures 4-1 and 4-2. The mixes were not quite self-leveling but a faster fill rate would have provided faster flow and better leveling. Two corners were $1 / 4$ of an inch lower than the corner where the material was discharged. The diagonal corner was only $1 / 8$ inch lower than the discharge point. The level inside and outside the cylinders was approximately the same.

\subsection{Boric Acid Addition Confirmation}

Tests were performed to identify the dose of boric set retarder in the blended calcium aluminate calcium sulfate cement grout mix. Results of selected tests are presented in Table 4.8 and were used to finalize the mix design used in the scale-up testing and vessel mock up fill tests at Gibson's Pressure Grouting Services, Inc. The set times of mixes containing boric acid doses of between 0.35 and 1.0 weight percent of the cementitious binder (Ciment Fondu ${ }^{\circledR}+$ Plaster of Paris) set within 24 hours which met the acceptance criteria for reactor vessel filling. However, the dynamic working times for the mixes with 0.35 and $0.5 \mathrm{wt} \%$ boric acid additions were less than one hour.

A boric acid dose of 1.4 weight percent of the cementitious binder did not set for several days. However this mix did set some time after 20 days and had a compressive strength of 980 psi after curing for 194 days at $100 \%$ relative humidity.

Since the static and dynamic working times for mixes containing 0.7 and $0.8 \mathrm{wt} . \%$ of the binder were acceptable, a dose of $0.75 \mathrm{wt} . \%$ of the binder was selected for the pumping and vessel fill mock-up tests. At this dose, static and dynamic working time requirements were met without the use of chilled water. 
Table 4-8. Summary of boric acid dose results.

\begin{tabular}{|c|c|c|c|c|c|}
\hline $\begin{array}{l}\text { Mix } \\
\text { No. }\end{array}$ & $\begin{array}{l}\text { Proportions } \\
\text { (wt. \%) }\end{array}$ & $\begin{array}{l}\text { Boric Acid } \\
\text { Wt \% of } \\
\text { total binder }\end{array}$ & Fresh Properties & Set time & $\begin{array}{l}\text { Compressive } \\
\text { Strength } \\
\text { (psi) }\end{array}$ \\
\hline T4-5 & $\begin{array}{lr}\text { Ciment Fondu }^{\circledR} & 9.03 \\
\text { Plaster of Paris } & 4.53 \\
\text { Class F-Fly Ash } & 15.27 \\
\text { Masonry Sand } & 51.41 \\
\text { Water } & 19.12 \\
\text { KIM }^{\circledR} 301 & 0.14 \\
\text { Diutan Gum } & 0.02 \\
\text { SIKA VC }^{\circledR} 2100 & 0.09\end{array}$ & $\begin{array}{c}0.35 \\
\text { Chilled } \\
\text { water }\end{array}$ & $\begin{array}{l}\text { Static flow } \\
8.1 \text { in. @ initial } \\
7.6 @ 15 \mathrm{~min} \\
6.9 @ 30 \mathrm{~min} \\
4 @ 45 \mathrm{~min} \\
\text { No bleed/settlement } \\
\text { Consistency of mortar } \\
\text { after } 1 \text { hr of mixing }\end{array}$ & $<24 \mathrm{hr}$ & $824 @ 24$ hr \\
\hline T4-10 & $\begin{array}{l}\text { Boric Acid as indicated } \\
\text { Water : (Fondu }+ \\
\text { Plaster of Paris) }=1.41 \\
\text { Water: SIKA ViscoCrete }{ }^{\circledR} \\
=\sim 208\end{array}$ & $\begin{array}{c}0.5 \\
\text { Ambient } \\
\text { temperature } \\
\text { water }\end{array}$ & $\begin{array}{l}\text { Static flow } \\
8.1 \text { in. @ initial } \\
7.5 @ 15 \mathrm{~min} \\
4.0 @ 30 \mathrm{~min} \\
0 @ 45 \mathrm{~min} \\
\text { No bleed/settlement } \\
\text { Consistency of mortar } \\
\text { after } 1 \mathrm{hr} \text { of mixing } \\
\text { Initial flow cone } 30 \mathrm{~s}\end{array}$ & $<24 \mathrm{hr}$ & $\begin{array}{c}1030 \text { psi@8 days } \\
1533 \text { psi@182 days }\end{array}$ \\
\hline T4-6 & & 0.53 & $\begin{array}{l}\text { Static flow } \\
8.1 \text { in. @ initial } \\
7.0 @ 15 \mathrm{~min} \\
6.8 @ 30 \mathrm{~min} \\
5.9 @ 45 \mathrm{~min} \\
\text { No bleed/settlement } \\
\text { Consistency of mortar } \\
\text { after } 1 \mathrm{hr} \text { of mixing }\end{array}$ & $<24 \mathrm{hr}$ & 908 psi@1 day \\
\hline T6-2 & & 0.7 & $\begin{array}{l}\text { Static flow } \\
8.3 \text { in. @ initial } \\
7.4 @ 15 \mathrm{~min} \\
5.8 @ 30 \mathrm{~min} \\
4.3 @ 45 \mathrm{~min} \\
\\
\text { Dynamic flow } \\
\text { Initial flow cone =29 s } \\
\text { No bleed/settlement }\end{array}$ & $<24 \mathrm{hr}$ & 1230 psi@4 days \\
\hline T4-15 & & 0.8 & $\begin{array}{l}\text { Static flow } \\
7.9 \text { in. @ initial } \\
6.3 @ 15 \mathrm{~min} \\
5.5 @ 30 \mathrm{~min} \\
4.9 @ 45 \mathrm{~min} \\
\text { Dynamic flow } \\
\text { Initial flow cone = 33 s } \\
\text { No bleed/settlement }\end{array}$ & $<24 \mathrm{hr}$ & 940 psi@7 days \\
\hline
\end{tabular}


Table 4-8 (continued). Summary of boric acid dose results.

\begin{tabular}{|c|c|c|c|c|c|}
\hline $\begin{array}{l}\text { Mix } \\
\text { No. }\end{array}$ & $\begin{array}{l}\text { Proportions } \\
\text { (wt. \%) }\end{array}$ & $\begin{array}{l}\text { Boric Acid } \\
\text { Wt \% of } \\
\text { total binder }\end{array}$ & Fresh Properties & Set time & $\begin{array}{l}\text { Compressive } \\
\text { Strength } \\
\text { (psi) }\end{array}$ \\
\hline T6-6 & \begin{tabular}{lr} 
Ciment Fondu $^{\circledR}$ & 9.03 \\
Plaster of Paris & 4.53 \\
Class F-Fly Ash & 15.27 \\
Masonry Sand & 51.41 \\
Water & 19.12 \\
KIM $^{\circledR}$ 301 & 0.14 \\
Diutan Gum & 0.02 \\
SIKA VC & 2100 \\
Boric Acid as indicated \\
\multicolumn{2}{l}{}
\end{tabular} & 0.79 & $\begin{array}{l}\text { Static flow after } 10 \\
\text { min mixing } \\
8.3 \text { in. @ initial } \\
7.3 @ 15 \mathrm{~min} \\
6.4 @ 30 \mathrm{~min} \\
5.9 @ 45 \mathrm{~min} \\
\text { Dynamic flow } \\
\text { Initial flow cone }=40 \mathrm{~s} \\
\text { after } 5 \mathrm{~min} \text { mixing } \\
30 \mathrm{~s} \text { after } 10 \text { min mixing } \\
\text { No bleed/settlement }\end{array}$ & $<24 \mathrm{hr}$ & NM \\
\hline T4-16 & $\begin{array}{l}\text { Water }:(\text { Fondu }+ \\
\text { Plaster of Paris })=1.41 \\
\text { Water: SIKA ViscoCrete } \\
=\sim 208\end{array}$ & 1.0 & $\begin{array}{l}\text { Static flow } \\
8.5 \text { in. @ initial } \\
7.3 @ 15 \mathrm{~min} \\
6.0 @ 30 \mathrm{~min} \\
5.3 @ 45 \mathrm{~min} \\
\\
\text { Dynamic flow } \\
\text { Initial flow cone = 31 s } \\
\text { No bleed/settlement }\end{array}$ & $<24 \mathrm{hr}$ & $\begin{array}{c}1682 \text { psi@ } 183 \\
\text { days }\end{array}$ \\
\hline T6-1 & & 1.4 & $\begin{array}{l}\text { Static flow } \\
8.68 \text { in. @ initial } \\
6.5 @ 15 \mathrm{~min} \\
6.8 @ 30 \mathrm{~min} \\
6.0 @ 45 \mathrm{~min} \\
\\
\text { Dynamic flow } \\
\text { Initial flow cone }=27 \mathrm{~s} \\
\text { Bleed } \\
\text { Gelled within } 24 \mathrm{hr} \\
\text { but did not set for } \\
\text { several weeks }\end{array}$ & $>20$ days & $\begin{array}{c}980 \text { psi @ } 194 \\
\text { days }\end{array}$ \\
\hline
\end{tabular}

$\mathrm{NM}=$ not measured.

\subsection{SRNL Calorimeter Results}

Adiabatic temperature rise was measured at SRNL in one of two adiabatic calorimeters. A list of mixes, results, and experimental approach are documented in a report [Steimke, 2010]. Three mixes tested are shown in Table 4-9. The temperature rises were added to the temperature of the starting material to obtain the maximum temperature resulting from the cementitious reactions. This method of estimating the adiabatic temperature rise for complete reaction was used for comparison of materials. Because the majority of the reactions in the calcium aluminate calcium sulfate - water system appear to be complete in 3 to 5 days, the estimate of the total heat generated is reasonable. ${ }^{15}$

\footnotetext{
${ }^{15}$ Steimke, et al., 2011, applied a factor of 1.4 to 1.5 to the calcium aluminate - calcium sulfate adiabatic calorimeter results based on prior experience with portland cement-based systems. A detailed analysis of the blended calcium aluminate - calcium sulfate system was not performed and the factor of 1.4 to 1.5 is probably overly conservative.
} 
Table 4-9. Calorimeter Mixes with Boric Acid

\begin{tabular}{|c|c|c|c|c|c|c|c|}
\hline Mix No. & $\begin{array}{l}\text { Proportion } \\
\text { (wt. \%) }\end{array}$ & & $\begin{array}{l}\text { Water: } \\
\text { Fondu+ } \\
\text { Plaster } \\
\text { of Paris }\end{array}$ & $\begin{array}{c}\text { Set } \\
\text { Time } \\
\text { (hours) }\end{array}$ & $\begin{array}{c}\text { Compressive } \\
\text { Strength } \\
\text { (psi) }\end{array}$ & $\begin{array}{l}\text { Maximum } \\
\text { Temp. rise in } \\
\text { calorimeter } \\
\left({ }^{\circ} \mathrm{C}\right)\end{array}$ & $\begin{array}{c}\text { Adiabatic } \\
\text { Temperature } \\
\text { Rise } \\
\left({ }^{\circ} \mathrm{C}\right) \\
\end{array}$ \\
\hline $\begin{array}{l}\mathbf{1 0 1 H} \\
1 / 2 \text { the target } \\
\text { amount of } \\
\text { binder } \\
0.75 \text { wt. \% } \\
\text { boric acid } \\
\text { based on } \\
\text { binder } \\
\text { Same mix as } \\
\text { T4-18 }\end{array}$ & $\begin{array}{l}\text { Ciment Fondu }^{\circledR} \\
\text { Plaster of Paris } \\
\text { Class F-Fly Ash } \\
\text { Masonry Sand } \\
\text { Water } \\
\text { KIM }^{\circledR} 301 \\
\text { Boric Acid } \\
\text { Diutan Gum } \\
\text { SIKA VC }{ }^{\circledR} 2100\end{array}$ & $\begin{array}{r}4.61 \\
2.30 \\
17.98 \\
55.30 \\
19.51 \\
0.14 \\
0.05 \\
0.02 \\
0.09\end{array}$ & 2.83 & 2.5 & $\begin{array}{c}190 \\
\text { @ } 1 \text { day } \\
\\
240 \\
\text { @ } 6 \text { days } \\
\text { (T4-18) }\end{array}$ & $\begin{array}{l}17.3 \\
\text { (initial temp. } \\
=23.4^{\circ} \mathrm{C} \text { ) }\end{array}$ & $\begin{array}{c}26 \\
(69 \mathrm{~J} / \mathrm{mL})\end{array}$ \\
\hline $\begin{array}{l}\text { 102H } \\
\text { Target } \\
\text { amount of } \\
\text { binder } \\
0.75 \text { wt. \% } \\
\text { boric acid } \\
\text { based on } \\
\text { binder } \\
\text { Same mix as } \\
\text { T12-1 } \\
\& \text { T10-1 }\end{array}$ & $\begin{array}{l}\text { Ciment Fondu } \\
\text { Plaster of Paris } \\
\text { Class F-Fly Ash } \\
\text { Masonry Sand } \\
\text { Water } \\
\text { KIM }^{\circledR} 301 \\
\text { Boric Acid } \\
\text { Diutan Gum } \\
\text { SIKA VC } \\
2100\end{array}$ & $\begin{array}{r}9.06 \\
4.53 \\
15.32 \\
51.56 \\
19.18 \\
0.14 \\
0.10 \\
0.02 \\
0.09\end{array}$ & 1.41 & 12 & $\begin{array}{c}760 \\
\text { @ } 5 \text { days } \\
\text { (T12-1) } \\
\\
760 \\
\text { @ } 5 \text { days } \\
\text { (T10-1) }\end{array}$ & $\begin{array}{l}35.5 \\
\text { (initial temp. } \\
=23.5^{\circ} \mathrm{C} \text { ) }\end{array}$ & $\begin{array}{c}54 \\
(130 \mathrm{~J} / \mathrm{mL})\end{array}$ \\
\hline $\begin{array}{l}\mathbf{1 0 3 H} \\
1 / 2 \text { target } \\
\text { amount of } \\
\text { binder } \\
83 \% \text { more } \\
\text { boric acid } \\
\text { than } 101 \mathrm{H} \\
\end{array}$ & $\begin{array}{l}\text { Ciment Fondu }^{\circledR} \\
\text { Plaster of Paris } \\
\text { Class F-Fly Ash } \\
\text { Masonry Sand } \\
\text { Water } \\
\text { KIM }^{\circledR} 301 \\
\text { Boric Acid } \\
\text { Diutan Gum } \\
\text { SIKA VC }^{\circledR} 2100 \\
\end{array}$ & $\begin{array}{r}.61 \\
2.30 \\
17.97 \\
55.28 \\
19.51 \\
0.14 \\
0.09 \\
0.02 \\
0.09 \\
\end{array}$ & 2.83 & 26 & $\begin{array}{l}\text { Not set at } \\
24 \mathrm{hr} \text {. }\end{array}$ & $\begin{array}{l}17.1 \\
\text { (initial temp. } \\
=25.5^{\circ} \mathrm{C} \text { ) }\end{array}$ & $\begin{array}{c}24 \\
(54 \mathrm{~J} / \mathrm{mL})\end{array}$ \\
\hline
\end{tabular}

$\mathrm{NM}=$ not measured.

Figure 4-4 shows the temperature rise inside the calorimeter for the three mixes in Table 4-9. Mix $102 \mathrm{H}$ had two times more binder (Ciment Fondu ${ }^{\circledR}+$ Plaster of Paris) than mixes $101 \mathrm{H}$ and $103 \mathrm{H}$. Consequently the adiabatic temperature rise was about twice of those mixes. The boric acid dose in Mix 103H was about $83 \%$ greater than the dose in Mix 101H. Both mixes had equal proportions of binder. The set time for Mix $103 \mathrm{H}$ was about 10 times longer than that for mix $101 \mathrm{H}$. The temperature rises for both mixes were about the same which was expected since they had identical proportions (except for the boric acid). Mixing times were also the same and performed in a Hobart planetary mixer at the same mixing speed setting. 


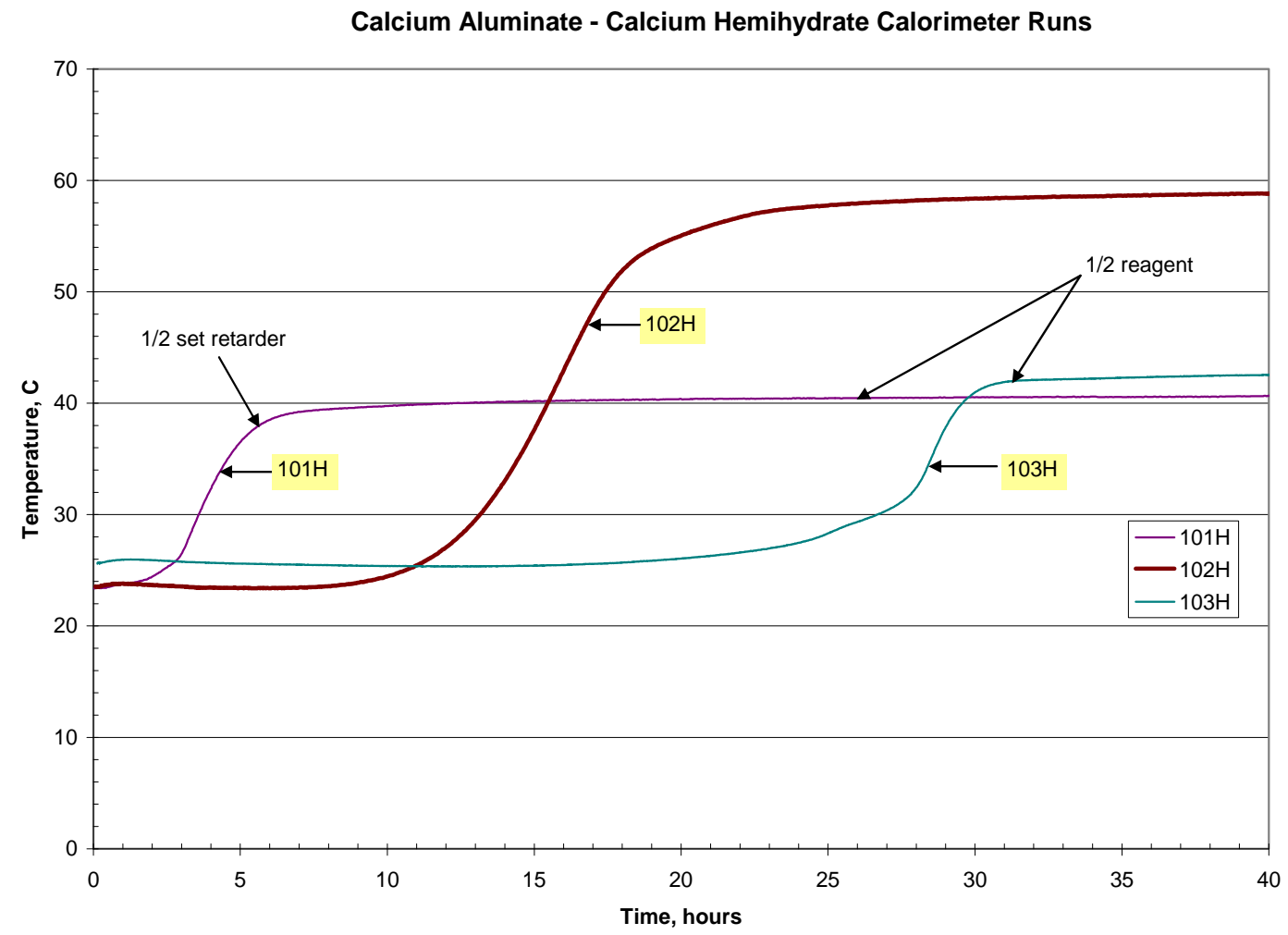

Figure 4-4. Adiabatic calorimeter result for selected mixes with different binder amounts and boric acid set retarder concentrations.

\subsection{Scale-up Testing at Gibson Pressure Grouting Service, Inc.}

The blended calcium aluminate - sulfate cement grout with boric acid set retarder was recommended for production scale-up and mock-up testing. The test objectives are described elsewhere [Stefanko, 2010] and include to:

- Confirm processability of the recommended blended calcium aluminate - sulfate cement grout including the boric acid dose

- Confirm the quality of grout produced with full-scale production equipment and methods.

- Prepare for full-scale P-Reactor vessel filling and included demonstration of blending and packaging of reagents, inert fillers, and processing admixture

- Identify a mixer (drum, paddle, colloidal or other) for the calcium aluminate - sulfate cement grout and prepare mixing specifications

- Identify a grout pump, demonstrate pumping at 3 flow rates through a $400 \mathrm{ft}$ recirculation loop, and determine the effect of mixing and recirculation (up to $1 \mathrm{hr}$ ) on material properties

- Identify hose sizing requirements required for grout placement into SRS reactor

- Identify suitable equipment for adding / metering liquid admixtures to the mixer

- Identify process instrumentation and monitoring requirements for full-scale production

- Identify QA tests and sampling frequency for full-scale production 
- Measure semi-adiabatic temperature rise for a one cubic yard monolith instrumented with thermocouples

- Demonstrate a dynamic working time and material properties for mixing up to 1 hour and evaluate contingencies for upset conditions

- Demonstrate grout flow and self-leveling in a $1 / 4$ scale vessel mock-up with representative flow obstructions

- Demonstrate a method for adding and metering water to mixer

- Demonstrate a method for adding dry solids to mixer

- Perform grout drop height test to identify any adverse effects on grout flow behavior and separation/segregation due to freefall

- Determine chilled water requirements

The testing was performed at Gibson's Pressure Grouting Services, Inc., Smyrna, GA during August and September, 2010. Details of the testing are provided in the Statement of Work, GSOW-G-00121 [Griffin, Langton, and Stefanko, 2010]. The mix recommended for the scale-up and vessel fill mock-up testing is provided in Table 4-10. More details of the scale-up and vessel fill mock-up testing are provided elsewhere [Serrato and Langton, 2010 and Blankenship, 2010].

Table 4-10. Blended calcium aluminate - calcium sulfate cement grout recommended for scale-up and mock-up testing.

\begin{tabular}{|l|c|c|c|c|}
\hline \multirow{2}{*}{ Ingredient } & \multicolumn{4}{|c|}{ Proportions } \\
\cline { 2 - 5 } & Wt. \% & $(0.25 \mathrm{cu} \mathrm{ft})$ & $(1.0 \mathrm{cu} \mathrm{ft})$ & $(1.0 \mathrm{cyd})$ \\
\hline Ciment Fondu $^{(B)}$ & 9.09 & $2.82 \mathrm{lbs}$ & $11.3 \mathrm{lbs}$ & $304.6 \mathrm{lbs}$ \\
\hline Plaster of Paris & 4.55 & $1.41 \mathrm{lbs}$ & $5.6 \mathrm{lbs}$ & $152.3 \mathrm{lbs}$ \\
\hline Class F Fly Ash & 15.38 & $4.77 \mathrm{lbs}$ & $19.1 \mathrm{lbs}$ & $515.2 \mathrm{lbs}$ \\
\hline Sand & 51.74 & $16.05 \mathrm{lbs}$ & $64.2 \mathrm{lbs}$ & $1733.4 \mathrm{lbs}$ \\
\hline Water & 19.25 & $5.97 \mathrm{lbs}$ & $23.9 \mathrm{lbs}$ & $644.8 \mathrm{lbs}$ \\
& & $0.72 \mathrm{gal}$ & $2.87 \mathrm{gal}$ & $77.4 \mathrm{gal}$ \\
\hline KIM $^{(} 301$ & -- & $19.09 \mathrm{~g}$ & $76.4 \mathrm{~g}$ & $2061.7 \mathrm{~g}$ \\
\hline Diutan Gum $^{\text {SIKA ViscoCrete }}{ }^{(}$ & -- & $2.16 \mathrm{~g}$ & $8.6 \mathrm{~g}$ & $233.3 \mathrm{~g}$ \\
\hline 2100 & -- & $12.95 \mathrm{~g}$ & $51.8 \mathrm{~g}$ & $1398.6 \mathrm{~g}$ \\
\hline Boric Acid* & -- & $5.97 \mathrm{~g}$ & $40.2 \mathrm{~g}$ & $1085.4 \mathrm{~g}$ \\
\hline
\end{tabular}

*Boric can be adjusted between 0.5 and $1.25 \mathrm{wt}$. \% of the binder depending on ambient temperature, reagent temperatures, and reactivity of the reagent batch.

\subsubsection{Scale-up Test Results}

The dry reagents for the mixing and pumping test were pre-blended and packaged in supersacks at Gibson's Pressure Grouting Services, Inc. Each sack contained 500 pounds of solid. The first mixer tested was a colloidal type. This mixer was too slow to incorporate the dry solids which were discharged from supersacks suspended above the mixing tank. Therefore a 25 cubic foot double tub paddle mixer was tested. The paddle blades were better at drawing the solids into the liquid which gave faster solids addition rate and shorter batch time. Photos of the mixing, pumping, static working time testing, and monolith and vessel filling are shown in Figure 4-5. 


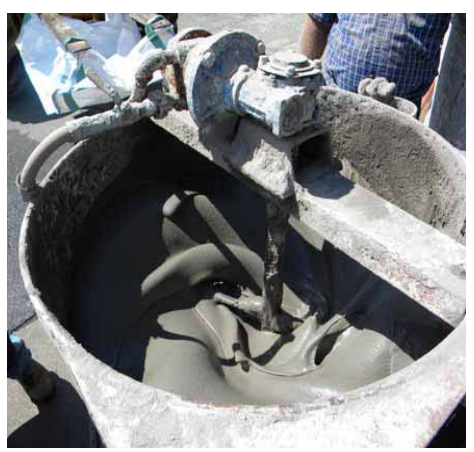

(a)

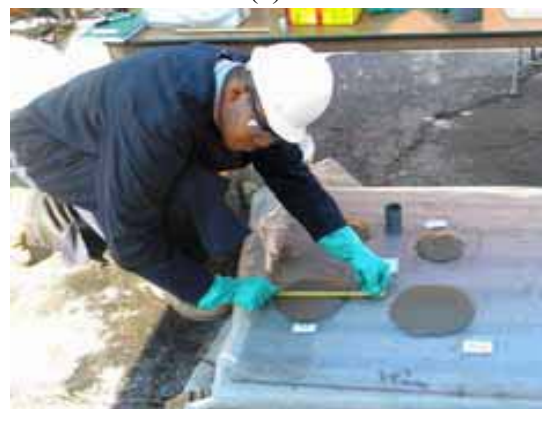

(d)

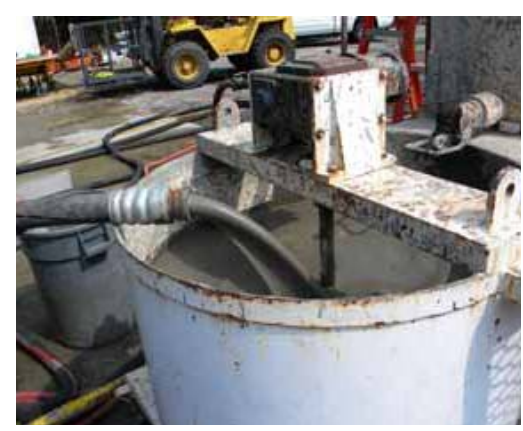

(b)

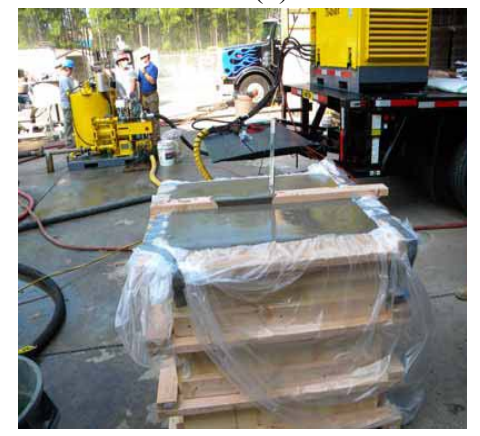

(e)

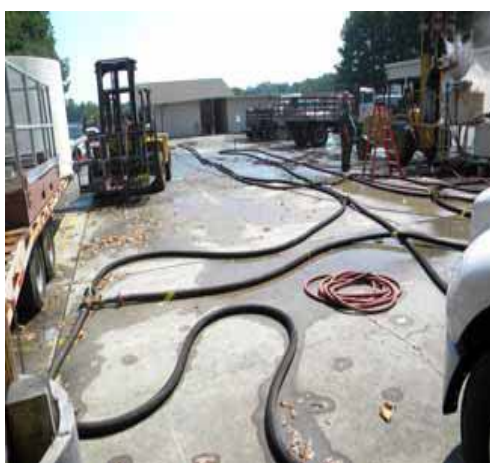

(c)

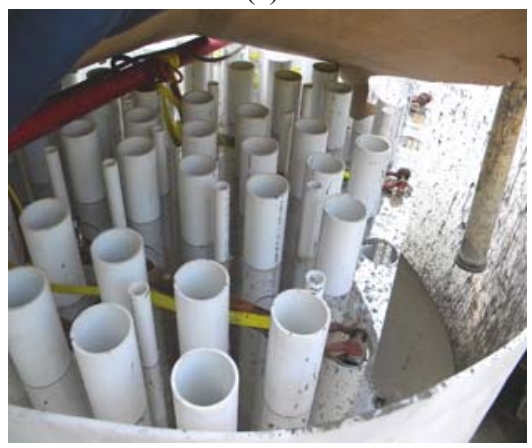

(f)

Figure 4-5. Scale-up Test. (a) Mixing Evaluation, (b and c) Re-circulating loop and Pump test, (d) Field static gel time test, (e) Semi-adiabatic temperature rise monolith, and (f) Mock-up vessel flow evaluation.

Once the mixer was selected, twenty five cubic feet ( 5 batches of dry reagents plus water) of grout were prepared for the pumping / recirculation loop test. A PUMPAC pumping system with a hydraulically driven ball and seat pump with a two stage piston was used. Grout was successfully pumped through $400 \mathrm{ft}$ of 2 inch flexible hose which recirculated back to the agitator hold tank. Pump rates were 10, 20, 30 and about $53 \mathrm{gpm}$. The slowest pump rate was tested first then the rate was increased sequentially. The ambient temperature during the pumping test was $92.8^{\circ} \mathrm{F}$. The grout temperature during mixing rose from $87.5^{\circ} \mathrm{F}$ to $96.5^{\circ} \mathrm{F}$ over a 68 minute period.

A 50 psi pressure loss was measured over 100 feet of 2 inch hose at the maximum flow rate. Pressure at the output of the pump was about 150 psi. Cold water was used to cool the mixer and hold tank prior to starting the test. Increasing recirculation time increased the fluidity of the mix as indicated by shorter flow cone measurements. The ASTM flow cone measurements were 24 seconds (30 minute) and 18.5 seconds (60 minute). Initial flows/spreads were 8.75 inch (30 minute) and 8.0 inch (60 minute).

After demonstration of pumping, dry reagents were blended to produce 6 cubic yards of grout for the $1 / 4$ scale vessel mock up demonstration and for filling a one cubic yard form for semi-adiabatic temperature measurements. Thermocouples were installed along a vertical support in the center of the plywood form. The thermocouples were spaced 8, 18, 24, and 30 inches from the bottom of the box. Temperature measurements were collected using a calibrated data logger over a period of 10 days. Results for the first 4 days are show in Figure 4-6. The temperature rise measured on the one cubic yard monolith was $53^{\circ} \mathrm{C}$. This compares very well with the $54^{\circ} \mathrm{C}$ 
adiabatic temperature rise calculated for Mix 102H (Table 4-9) which has the same proportions as the monolith. The peak temperature occurs in about 10 hours which is consistent with results from laboratory samples.

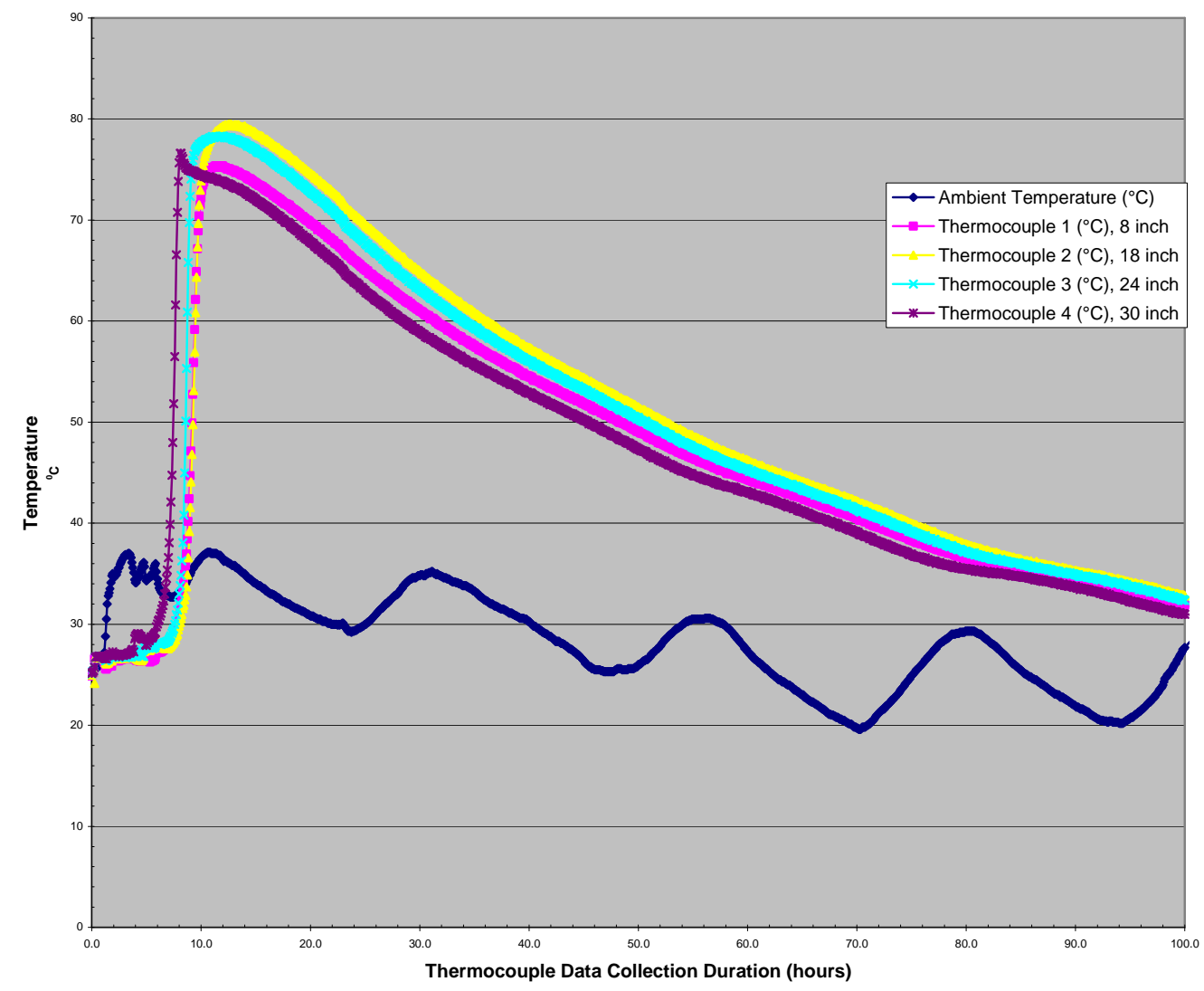

\section{Figure 4-6. Blended calcium aluminate - calcium sulfate cement grout semi-adiabatic temperature results for one cubic yard monolith prepared on 9-2-2010.}

Five cubic yards of the blended calcium aluminate - calcium sulfate cement grout were placed during the vessel fill mock up test, September 2, 2010. The grout was dropped about $20 \mathrm{ft}$ (free fall) into the vessel. No segregation was observed and splatter was controlled by the SONO tube used as a guide for the grout stream. The flow rate was progressively increased from 20 gpm (run for 6 minutes) to $30 \mathrm{gpm}$ (run for 4 minutes) to the maximum pump rate of about $50 \mathrm{gpm}$. The total height of the grout in the tank was about 24 inches. The grout flowed around simulated obstructions, i.e., 4 inch and 1.5 inch PVC pipes representing Universal Sleeve Housings and thimbles, respectively. The difference between level of the grout at the placement point to the opposite side of the tank was less than 1 inch. The number and positions of these obstructions represented the actual conditions in the P-Reactor vessel and were specified by SDD Engineering [Griffin, 2010]. Based on these results and information from samples collected from scale-up tests, the blended calcium aluminate - calcium sulfate grout was selected for the filling P-Reactor Vessel. 


\subsection{Blended Calcium Aluminate - Calcium Sulfate Grout Mineralogy and Microstructure}

Mineralogy and microstructure characterization was performed on a sample taken from the one cubic yard block cast for temperature measurements as part of the mock-up test. See Figure 4- 7. The sample was prepared for powder pattern X-ray diffraction analysis by crushing cured grout to -100 mesh. Ettringite was identified as the primary crystalline cementitious phase. The fine aggregate in the grout was quartz and this mineral was also observed in the XRD patterns. See Figure 4-8. Trace amounts of mullite, $\mathrm{Al}_{6} \mathrm{Si}_{2} \mathrm{O}_{13}$, from the fly ash (glass spheres which often contain mullite and cristobalite as refractory phases formed during quenching) was detected in some of the samples analyzed. Amorphous aluminum hydroxide is also present but does not show up in an XRD pattern. Anhydrous calcium aluminate phases in the Ciment Fondu ${ }^{\circledR}$ were also detected in trace amounts. However, the identification of the anhydrous phases is questionable because of the small quantities. Calcium sulfate hemihydrate, and calcium sulfate dihydrate were not present in the hydrated material.
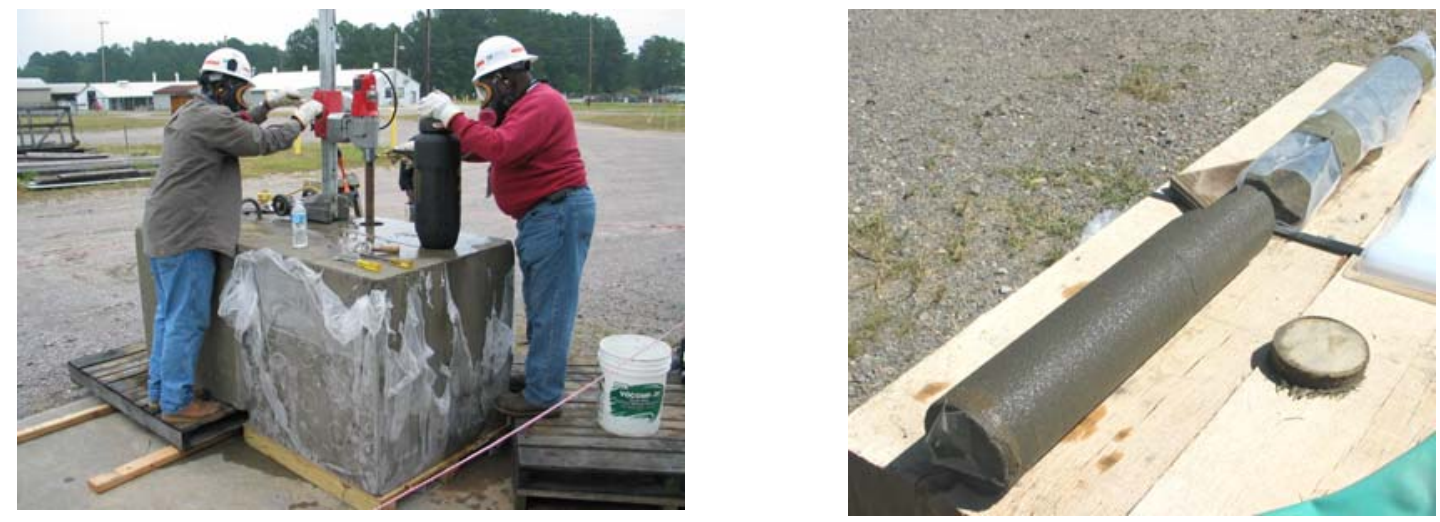

Figure 4-7. Core drilling of the monolith. Samples used for XRD, SEM and strength.

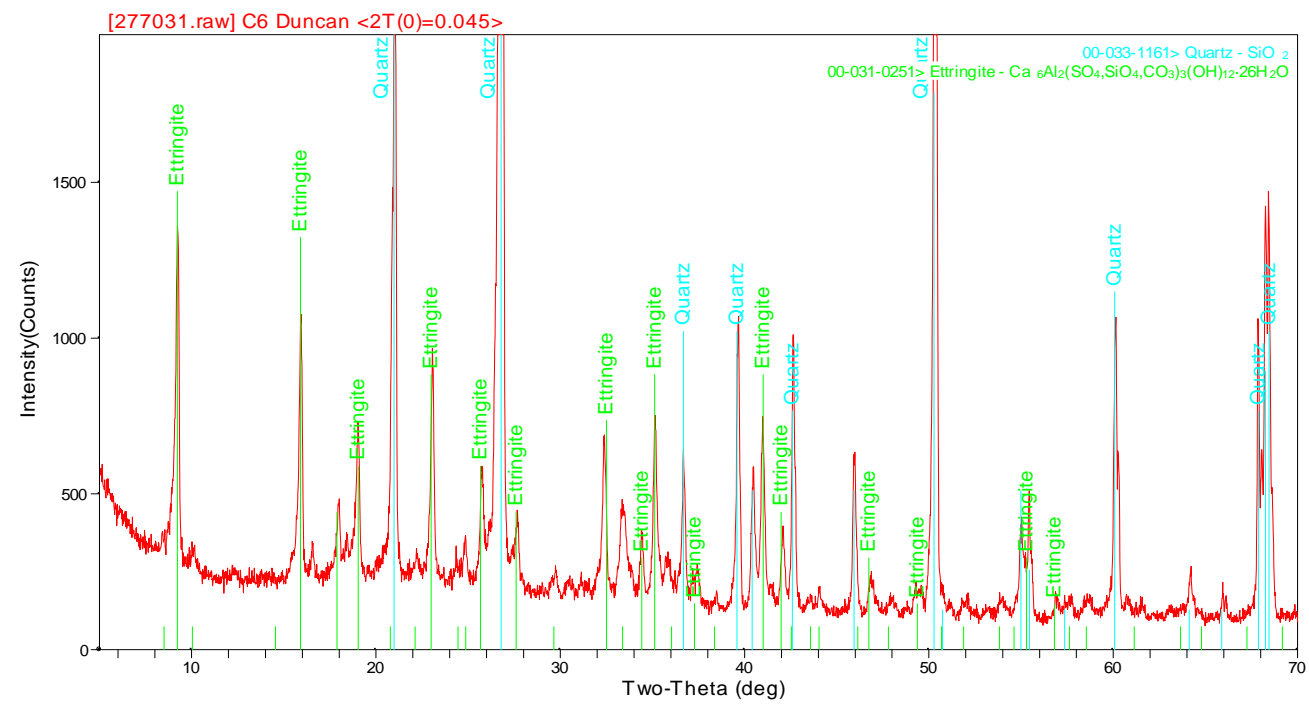

Figure 4-8. X-ray diffraction of hydrated blended calcium aluminate - calcium sulfate (2:1 by weight) cement grout. Ettringite is the only cementitious crystalline phase. Quartz sand, the fine aggregate in the grout is also present in the sample analyzed. 
Scanning electron microscopy was used to characterize the microstructure of the blended calcium aluminate - calcium sulfate-based grout. Back scattered electron images are shown in Figure 4-9. Needles of ettringite form an interlocking matrix around fly ash particles (spherical) and quartz sand grains (irregular to equant grains). Amorphous aluminum hydroxide is present as an interstitial phase between the ettringite crystals and other particles. (See Figure 4-9 5000X magnification). Several morphologies were observed for ettringite; long well defined interlocking needles are embedded in short stubby needles.

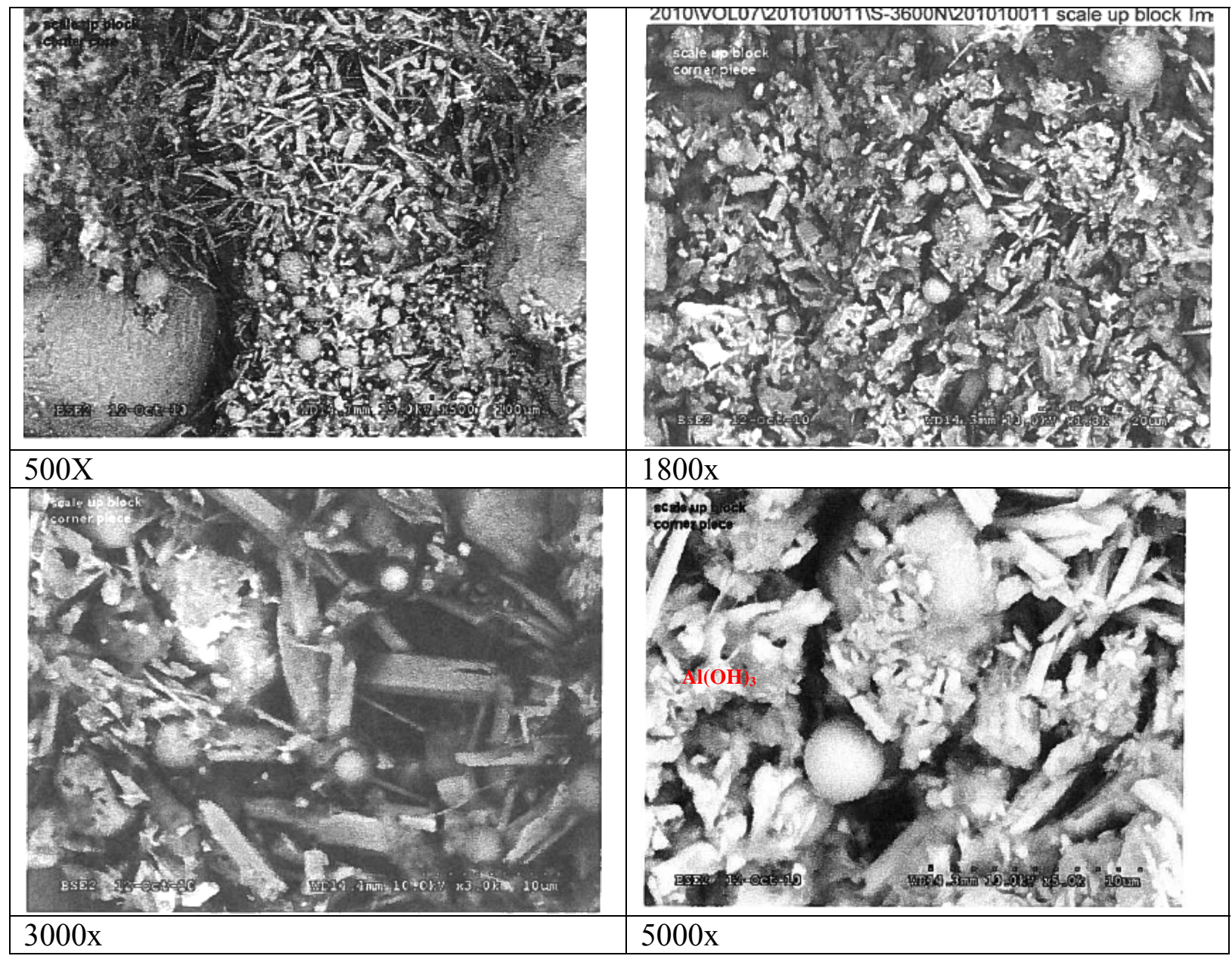

Figure 4-9. Microstructure of the hydrated blended calcium aluminate - calcium sulfate cement-based grout.

The average compressive strength measured from cores taken from the monolith was 950 psi and the average saturated hydraulic conductivity was $3 \mathrm{E}-06 \mathrm{~cm} / \mathrm{s}$ (measured by ASTM D-5084). 


\subsection{DISCUSSION AND CONCLUSIONS}

Blended calcium aluminate - calcium sulfate cement met the chemical and mineralogical requirements for a reactor fill grout. The $\mathrm{pH}$ of water in contact with fresh and cured cement was 9 to 10 which met the requirement of $<10.5$, and the primary cementitious phase was ettringite which is stable in this system. Aluminum hydroxide was also formed in the matrix and is compatible with the materials of construction for the reactor vessel and internal components. Ciment Fondu ${ }^{\circledR}$ and Plaster of Paris were identified as commercially available components which could be blended in a ratio of 2 to 1 by weight to produce a hydrated matrix consisting of ettringite and amorphous aluminum hydroxide. This blend of ingredients required a set retarder as indicated by static working times of less than 15 minutes. Citric acid and boric acid were effective set retarders. A lower dose of citric acid was required compared to boric acid for the same set delay. Boric acid was selected for the scale-up testing and subsequently the final mix because it was available at Gibson's Pressure Grouting Services, Inc. during the scale-up testing.

A grout fill requires inert fillers in addition to a suitable cement binder. The inert fillers used in the blended calcium aluminate - calcium sulfate cement grout were the same as those specified for the magnesium potassium phosphate flowable fill developed in an earlier study [Stefanko, 2010]. A bimodal particle size distribution was found to be effective in reducing segregation and enhancing flow behavior. Consequently, a mixture of Class F fly ash and quartz sand (ASTM C404 masonry sand or ASTM C-637 Grade 2 sand) in a ratio of about 1:3 was selected for the blended calcium aluminate - calcium sulfate cement grout.

Based on laboratory bench-scale and bench scale-up testing and the mixing, pumping and $1 / 4$ scale mock up testing at Gibson's Pressure Grouting Services, Inc., a blended calcium aluminate calcium sulfate cement grout with a water to binder ratio of 1.41 was selected as the reactor fill production grout. Proportions and fresh and cured properties are provided in Tables 5-1 and 5-2, respectively.

After the grout mock up testing, formulation adjustments to lower the water to binder ratio were tested. This work was performed because full-scale mixing (better agitation) resulted in more fluid grouts than what had been achieved during bench-scale mixing. These adjustments consisted of replacing water with ASTM C 637 gradation 2 sand, reducing the amount of diutan gum, and adding a small amount of additional HRWR (SIKA ViscoCrete 2100). This effort resulted in development of a second blended calcium aluminate - calcium sulfate cement grout with 12 wt.\% less water. The proportions and properties are listed in Tables 5-1 and 5-2, respectively. Since full-scale testing was not performed on this formulation, it was not recommended as the production fill material. However, the reduction in water to binder resulted in higher compressive strengths and is expected to result in lower porosity and permeability. (This mix is very sensitive to the amount of SIKA ViscoCrete 2100. A small amount of additional SIKA ViscoCrete 2100 resulted in delaying set and lower early strengths.) 
Table 5-1. Blended calcium aluminate - calcium sulfate grouts developed for P-Reactor vessel ISD.

\begin{tabular}{|c|c|c|c|c|}
\hline \multirow[b]{2}{*}{ Ingredient } & \multicolumn{2}{|c|}{$\begin{array}{l}\text { Water to binder weight } \\
1.41\end{array}$} & \multicolumn{2}{|c|}{$\begin{array}{c}\text { Water to binder weight } \\
1.24\end{array}$} \\
\hline & $\left(\mathbf{L b s} / \mathrm{yd}^{3}\right)$ & $\left(\mathrm{Kg} / \mathrm{yd}^{3}\right)$ & $\left(\mathbf{L b s} / \mathrm{yd}^{3}\right)$ & $\left(\mathrm{Kg} / \mathrm{yd}^{3}\right)$ \\
\hline $\begin{array}{l}\text { Ciment Fondu } \\
\text { (Kerneos Aluminate Technologies) }^{\circledR}\end{array}$ & 304.3 & 180.5 & 304.3 & 180.5 \\
\hline $\begin{array}{l}\text { Plaster of Paris } \\
\text { (US Gypsum Company) }\end{array}$ & 152.2 & 90.3 & 152.2 & 90.3 \\
\hline $\begin{array}{l}\text { Class F Fly Ash ASTM C-616 } \\
\text { (SEFA, Inc.) }\end{array}$ & 514.8 & 305.4 & 514.8 & 305.4 \\
\hline $\begin{array}{l}\text { ASTM C-404 Masonry sand or } \\
\text { ASTM C-637 Sand for grout for } \\
\text { pre-placed aggregate }\end{array}$ & 1732.0 & 1027.6 & 1937 & 1150 \\
\hline Water & 644.3 & 382.2 & 566.9 & 366.4 \\
\hline $\begin{array}{l}\text { KIM }^{\circledR} 301 \text { (Integral Water } \\
\text { Proofing Admixture) } \\
\text { (Kryton, International Inc.) }\end{array}$ & 4.5 & 2.7 & 4.5 & 2.7 \\
\hline $\begin{array}{l}\text { SIKA ViscoCrete }{ }^{\circledR} 2100 \\
\text { (W.R. Grace, Inc.) }\end{array}$ & 3.1 & 1.8 & 3.4 & 2.0 \\
\hline Diutan Gum (CP Kelco, Inc.) & 0.5 & 0.3 & 0.17 & 0.1 \\
\hline $\begin{array}{l}\text { Boric Acid (if needed) } \\
\text { (Alfa Aesar) }\end{array}$ & 3.4 & 2.0 & 3.4 & 2.0 \\
\hline Total & 3359 & 1993 & 3487 & 2069 \\
\hline
\end{tabular}

Table 5-2. Properties of P-Reactor vessel blended calcium aluminate-calcium sulfate cement grouts

\begin{tabular}{|c|c|c|}
\hline Property & \multirow{2}{*}{$\begin{array}{l}\text { Water to binder weight } \\
1.41\end{array}$} & \multirow{2}{*}{$\begin{array}{c}\text { Water to binder weight } \\
1.24\end{array}$} \\
\hline Slurry Properties (Fresh Properties) & & \\
\hline pH P-Reactor Vessel & $\begin{array}{l}9 \text { to } 10 \text { fresh slurry and water } \\
\text { in contact with cured sample }\end{array}$ & $\begin{array}{l}9 \text { to } 10 \text { fresh slurry and water } \\
\text { in contact with cured sample }\end{array}$ \\
\hline Flow Cone & $40 \mathrm{~s}$ (average) & $41 \mathrm{~s}$ \\
\hline Static Working Time & $45 \mathrm{~min}$. & 45 minutes \\
\hline Dynamic Working Time & $2-4 \mathrm{hr}$ & $\sim 4 \mathrm{hr}$ \\
\hline Set Time & $\sim 4 \mathrm{hr}$ & $\sim 24 \mathrm{hr}$ \\
\hline Density (wet unit weight) & $\begin{array}{r}1986 \mathrm{~kg} / \mathrm{m}^{3} \\
124 \mathrm{lbs} / \mathrm{ft}^{3} \\
\end{array}$ & $\begin{array}{r}2066 \mathrm{~kg} / \mathrm{m}^{3} \\
129 \mathrm{lbs} / \mathrm{ft}^{3} \\
\end{array}$ \\
\hline Bleed water & None & None \\
\hline Segregation & None & None \\
\hline Maximum particle size & $1 \mathrm{~mm}$ maximum & $1 \mathrm{~mm}$ maximum \\
\hline \multicolumn{3}{|l|}{ Cured Properties Compressive Strength } \\
\hline 3 days & $\begin{array}{l}5.24 \mathrm{MPa} \\
760 \mathrm{psi}\end{array}$ & $\begin{array}{l}4.55 \mathrm{MPa} \\
660 \mathrm{psi}\end{array}$ \\
\hline 7 day & $\begin{array}{l}7.22 \mathrm{MPa} \\
1047 \mathrm{psi}\end{array}$ & $\begin{array}{l}12.89 \mathrm{MPa} \\
1870 \mathrm{psi}\end{array}$ \\
\hline 28 days & $\begin{array}{l}7.5 \mathrm{MPa} \\
1084 \mathrm{psi}\end{array}$ & Not measured \\
\hline Saturated Hydraulic Conductivity & $3 \mathrm{E}-06 \mathrm{~cm} / \mathrm{s}$ & $4.1 \mathrm{E}-07 \mathrm{~cm} / \mathrm{s}$ \\
\hline Adiabatic temperature rise & $54^{\circ} \mathrm{C}$ & $\sim 51^{\circ} \mathrm{C}$ estimate \\
\hline
\end{tabular}




\subsection{RECOMMENDATIONS}

SRNL Mix T12-1 (Ciment Fondu ${ }^{\circledR}, 9.06$ wt. \%; Plaster of Paris, 4.53 wt. \%; ASTM C-637 gradation 2 quartz sand, 51.56 wt. \%; Class F fly ash, 15.32 wt.\%; KIM ${ }^{\circledR} 301,0.135$ wt. \%; SIKA ViscoCrete $^{\circledR} 2100,0.092$ wt. \%; boric acid, 0.10 wt. \% (0.75 wt. \% of the binder); diutan gum, 0.015 wt. \%; and water 19.18 wt. \% is recommended for filling the SRS P-Reactor Vessel. A bimodal distribution of inert fillers (powder and sand) is recommended to achieve a low heat, stable slurry. The recommended mix is shown in Table 6-1.

Table 6-1. Recommended blended calcium aluminate - calcium sulfate cement grout for P-Reactor vessel ISD.

\begin{tabular}{|c|c|c|}
\hline \multirow[b]{2}{*}{ Ingredient } & \multicolumn{2}{|c|}{ Water to binder weight 1.41} \\
\hline & $\left(\mathrm{Lbs} / \mathrm{yd}^{3}\right)$ & $\left(\mathrm{Kg} / \mathrm{m}^{3}\right)$ \\
\hline $\begin{array}{l}\text { Ciment Fondu }{ }^{\circledR} \\
\text { (Kerneos Aluminate Technologies) }\end{array}$ & 304.3 & 180.5 \\
\hline $\begin{array}{l}\text { Plaster of Paris } \\
\text { (US Gypsum Company) }\end{array}$ & 152.2 & 90.3 \\
\hline $\begin{array}{l}\text { Class F Fly Ash ASTM C-616 } \\
\text { (SEFA, Inc.) }\end{array}$ & 514.8 & 305.4 \\
\hline $\begin{array}{l}\text { ASTM C-404 Masonry sand or } \\
\text { ASTM C-637 Sand for grout for pre-placed } \\
\text { aggregate }\end{array}$ & 1732.0 & 1027.6 \\
\hline Water & 644.3 & 382.2 \\
\hline $\begin{array}{l}\text { KIM }^{\circledR} 301 \text { (Integral Water Proofing Admixture) } \\
\text { (Kryton, International Inc.) }\end{array}$ & 4.5 & 2.7 \\
\hline SIKA ViscoCrete ${ }^{\circledR} 2100$ (W.R. Grace, Inc.) & 3.1 & 1.8 \\
\hline Diutan Gum (CP Kelco, Inc.) & 0.5 & 0.3 \\
\hline Boric Acid (Technical grade) & 3.4 & 2.0 \\
\hline Total & 3359 & 1993 \\
\hline
\end{tabular}

* Proportions per unit volume were confirmed on large size batches.

Pre-blending of all of the solid ingredients is recommended for quality control and for simplifying full-scale production of this special material. Pre-measuring the SIKA ViscoCrete ${ }^{\circledR} 2100$ HRWR for each batch is also suggested.

The recommended mix design does not required use of chilled water for ambient temperatures up to $32^{\circ} \mathrm{C}$ provided the grout is continually agitated and placed within an hour after solids addition.

The mixing and pumping equipment used in the full-scale mixing and pumping test are suitable for full-scale production, i.e., double tub 25 cubic foot paddle mixer and 25 cubic foot agitator tank, PUMPAC hydraulically driven ball and seat pump with a two stage piston, and two inch flexible grout hose.

A minimum of 8 minutes of mixing (measured from the time all of the solids are added to the water) is required to achieve uniform properties during full-scale mixing. 


\subsection{QUALITY ASSURANCE}

Work was performed in accordance with TT/QAP SRNL-RP-2009-01248, Revision 0 using calibrated laboratory and test equipment. Results are recorded in Laboratory Notebooks SRNLNB-2009-00166 (mix formulations), SRNL-NB-2010-00120 (scale up), WSRC-2004-NB-0064, and SRNL-NB-2009-00162 (calorimeter data).

\subsection{ACKNOWLEDGEMENTS}

The blended calcium aluminate - calcium sulfate grouts developed at SRNL were funded by ARRA and SRNS/SDD-Engineering for SRS P-Reactor vessel in-situ decommissioning.

Support and technical expertise from the following researchers was much appreciated and essential to this effort. Justin Waymer and David Matheny, SRNL summer interns, prepared most of the samples generated for this study under the supervision of W. B. Mhyre, and A. G. Isherwood. W. Pope Jr., URS Washington Group, Quality and Testing Division, provided technical expertise, testing, and use of the SRS Civil Engineering Laboratory for conducting this study. H. N. Guerrero, J. L. Steimke, Q. H. Zafar, and M. L. Restivo, SRNL, performed the calorimeter testing. N. J. Vrettos, J. T. Bobbitt III, SRNL, provided drawings and models of the P-Reactor Vessel which were essential for visualizing flow paths and for designing the placement strategy. P. E. O'Rourke, D. E. Missimer, T. B. Curtis, and A. J. Duncan, SRNL, provided characterization of the materials. M. G. Serrato, SRNL, managed this project and served as liaison between D\&D and the SRNL technical resources. J. K. Blankenship and W. B. Griffin, provided much appreciated project review and support for this effort. 


\subsection{REFERENCES}

Blankenship, J. K. 2009. Personal communication with C. A. Langton and M. S. Serrato.

Blankenship, J. K. 2010. "Additional Test Results and Conclusions (105-P RV) - $1 \mathrm{yd}^{3}$ Calcium Alumino Sulfate Grout Block," SDD-2010-00234, October 6, 2010, Savannah River Nuclear Solutions, Aiken SC 29808.

Bobbitt, J. and N. J. Vrettos, 2010. P-Reactor Vessel Scale Model, SRNL-L3100-2010-00093, Savannah River National Laboratory, Savannah River Nuclear Solutions, Aiken SC 29808.

Crawford, C. L., 2009. Personal Communication of Data to C. A. Langton, Savannah River National Laboratory, Aiken, SC 29808.

Glasser, F. P. and L. Zhang, 2001. "High-performance Cement Matrices Based on Calcium Sulfoaluminate-belite Compositions," Cement and Concrete Research 31, p. 1881-1886.

Griffin, W. B., C. A. Langton, and D. B. Stefanko, 2010. "Reactor Vessel Grout Scale-up Testing and Material Mixing / Pumping for Placement (U)," G-SOW-G-00121, Savannah River Nuclear Solutions, Aiken, SC 29808.

Griffin, W. B., 2010a. “Grout Placement Strategy for 105-P Reactor Vessell,” SDD-2010-00200, Revision 1, October 21, 2010, Savannah River Nuclear Solutions, Aiken, SC 29808.

Griffin, W. B., 2010b. "Verification of Successful Filling 105-P RV with Grout," SDD-201000273, December 13, 2010, Savannah River Nuclear Solutions, Aiken, SC 29808.

Guerrero, H. N., 2009. Thermo-Physical Characterization of Reactor Vessel Fill Materials for Pand R- Reactor In-Situ Decommissioning," SRNL-RP-2009-01185, September, 2009, Savannah River National Laboratory, Aiken, SC 29808.

Guerrero, H. N., 2010. Personal Communication of Data to D. B. Stefanko, Savannah River National Laboratory, Aiken, SC 29808.

Guerrero, H. N., et al, 2009. "Measurement of Thermo-Physical Parameters of Base Portland Cement and Ceramicrete ${ }^{\circledR}$ Grout," SRNL-L3100-2009-00266, October 29, 2009, Savannah River National Laboratory, Savannah River Nuclear Solutions, Aiken SC 29808.

Hayes, M. and I. H. Godfrey, 2007. "Development of the Use of Alternative Cements for the Treatment of Intermediate Level Waste," WM Symposium 2007, February 25 to March 1, 2007, Tucson, AZ.

Musall, J. C. 2009a. SDD Engineering, Technical Assistance Request, “Grout/Concrete (Cementitious Materials) Related Engineering Activities Needed to Support PAOU Remedial Action Final Design," TAR-SDD-2008-00133, Savannah River Nuclear Solutions, Aiken, SC 29808. 
Musall, J. C. 2009b. SDD Engineering, Technical Assistance Request, "Grout/Concrete (Cementitious Materials) Related Engineering Activities Needed to Support 105-P and 105-R Reactor ISD Project," TAR-SDD-2008-00231, November 3, 2009, Savannah River Nuclear Solutions, Aiken, SC 29808.

Odler, I., 2000. Special Inorganic Cements, E\&FN SPON, NY, NY.

PAOU Final Action Reactor Building Complex, 2008. Q-MT-P-00003, October 21, 2008, Savannah River Site, Aiken, SC 29808.

Peysson, S., J. Pera, and M. Chabannet, 2005. "Immobilization of Heavy Metals by Calcium Sulfoaluminate Cement," Cement and Concrete Research, 35, p. 2261-2270.

Reyes-Jimenez, J., 2010. "Radiolysis Calculation for R and P Reactor Vessel Walls for Deactivation and Decommissioning Activities," N-CLC-P-00004, February 16, 2010, Savannah River Nuclear Solutions, Savannah River Site, Aiken, SC 29808.

Serrato, M. G., and C. A. Langton, 2010. "105-P Reactor Vessel Fill Materials - Calcium Aluminate Sulfate Mix Design," SRNL-L6100-2010-00013, Memorandum to J. C. Musall and J.K. Blankenship, October 14, 2010, Savannah River National Laboratory, Savannah River Nuclear Solutions, Aiken, SC 29808.

Stefanko, D. B., 2009a. "Reactor Vessel Fill Feasibility Study: Magnesium Potassium Phosphate Cement Grout, Laboratory Test Plan, SRNL-RP-2009-01501," Savannah River National Laboratory, Savannah River Nuclear Solutions, Aiken, SC 29808.

Stefanko, D. B., 2009b. "Design, Testing and Recommendations for SRS Reactor Vessel Fill Materials, Task Technical and Quality Assurance Plan," SRNL-RP-2009-01248, Rev. 0, October 5, 2009, Savannah River National Laboratory, Savannah River Nuclear Solutions, Aiken, SC 29808.

Stefanko, D. B., 2010. "Reactor Vessel In-Situ Decommissioning Grout Scale-up, Phase 1 Test Plan," SRNL-RP-2010-00236-DRAFT B, February 2010, Savannah River National Laboratory, Savannah River Nuclear Solutions, Aiken, SC 29808.

Stefanko, D. B., and C. A. Langton, 2010. Trip Report - Gibson's Pressure Grouting Service, Inc. February 25, 2010," SRNL-L3100-2010-00049, Rev. 0, Memorandum to M. G. Serrato, Savannah River National Laboratory, Savannah River Nuclear Solutions, Aiken, SC 29808.

Stefanko, D. B., C. A., Langton, and D. Singh, 2010. "Magnesium Mono Potassium Phosphate Grout for P-Reactor Vessel In- Situ Decommissioning (U)," SRNL-STI-2010-00333, Revision 0, January 5, 2011, Savannah River Nuclear Solutions, Aiken, SC 29808.

Steimke, J. L., Z. H. Qureshi, M. L. Restivo, and H. N. Guerrero, 2010. "Reactor Grout Thermal Properties," SRNL-STI-2010-00806, January 2011, Savannah River National Laboratory, Savannah River Nuclear Solutions, Aiken, SC 29808. 
Taylor, H. F. W., 1997. Cement Chemistry, Thomas Telford, London, UK.

Vrettos, N. J., 2009. Personal Communication / PowerPoint Presentation, November 2009, Savannah River National Laboratory, Savannah River Nuclear Solutions, Aiken, SC 29801.

Wiersma, B. J., 2009a. "Reactive Metal (Al) Interactions During Grouting Operations of the Rand R-Reactor Vessel," SRNL-RP-2009-01198, Rev. 0, September 2009, Savannah River National Laboratory, Aiken, SC 29808.

Wiersma, B. J., 2009b. "Assessment of the Potential for Hydrogen Generation During Grouting Operations in the R- and P- Reactor Vessels," SRNL-STI-2009-00639, Rev. 0, October 2009, Savannah River National Laboratory, Savannah River Nuclear Solutions, Aiken, SC 29808.

Wiersma, B. J. 2010. "Assessment of the Potential for Hydrogen Generation During Grouting Operations in the R- and P- Reactor Vessels," SRNL-STI-2009-00639, Rev. 2, May, 2010, Savannah River National Laboratory, Savannah River Nuclear Solutions, Aiken, SC 29808.

Zhou, Q. N. B. Milestone, and M. Hayes, 2006. "An Alternative to Portland Cement for Waste Encapsulation - The Calcium Sulfoaluminate Cement System," Journal of Hazardous Materials, 136, p. 120-129, 2006. 
SRNL-STI-2010-00427Revision 0 March 10, 2011

BLANK PAGE 


\section{DISTRIBUTION:}

R. J. Abitz, 773-43A

A. B. Barnes, 999-W

J. K. Blankenship, 707-25B

B. J. Giddings, 786-5A

J. C. Griffin, 773-A

W. B. Griffin, 707-25B

H. N. Guerrero, 786-5A

A. G. Isherwood, 241-154H

C. A. Langton, 773-43A

J. T. Long, 730-4B

S. L. Marra, 773-A

J. J. Mayer II, 773-42A

W. L. Mhyre, $717-5 \mathrm{~N}$

J. C. Musall, 707-25B

F. M. Pennebaker, 773-42A

W. Pope, Jr., 717-5N

M. G. Serrato, 773-42A

D. B. Stefanko, 773-43A

J. L. Steimke, 786-5A

J. T. Waymer, $717-5 \mathrm{~N}$

STI 